\title{
النشاطات العلمية لفروع الكلية
}

اولاً: النشاطات العلمية لفرع الدر اسات الدولية لسنة 2014 -

عقد فرع الدراسات الدولية يوم الأربعاء المصادف 2014/11/5 ندوته الفصلية الثانية الموسومة (الانتشار النووي بعد الحرب الباردة) برئاسة الاستاذ المساعد الدكتور سمير جسام راضي, وحضور أساتذة وتدريسيي الفرع. وقد قام بعض الاساتذة والتدريسيين بعرض مجموعة أوراق بحثية تناولت الموضوعات الآتية:

\begin{tabular}{|c|c|c|}
\hline 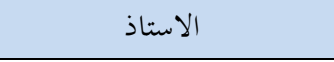 & 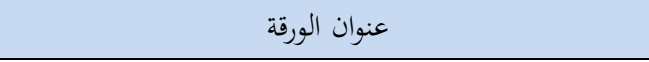 & $ت$ \\
\hline أ.م.د. إيناس عبد السادة علي & الانتشار النووي والاستقرار الدولي & 1 \\
\hline أ.م.د. صباح نعاس شنافة & المنظمات غير الحكومية ومساعي إهاء أسلحة الدمار الشامل & 2 \\
\hline م.د. عادل عبد الحمزة ثجيل & العصر النووي الثاني رؤية بول براكن & 3 \\
\hline م.د. غهرين جواد شرقي & الانتشار النووي وآفاقه المستقبلية & 4 \\
\hline م.د. حسين مزهر خلف & التداعيات الاقليمية للملف النووي الأيراني & 5 \\
\hline
\end{tabular}

وجرت بعد العرض مناقشة مفتوحة للأفكار التي وردت في هذه الأوراق، كانت مخرجاقا جملة

$$
\text { من الأطروحات المتعلقة بمسألة الأنتشار النووي ومنها: }
$$

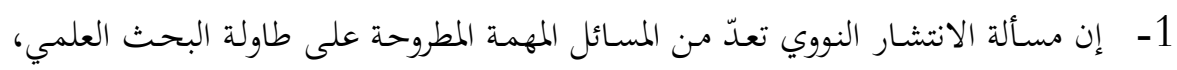
وإن الجوانب النظرية المتعلقة بنظرية الانتشار تتطلب استمرار المتابعة والرصد.

2- أن للانتشار النووي علاقة مباشرة بالاستقرار الاقليمي والدولي.

3- إن الانتشار النووي يطرح جملة من التحديات على المستوى الاقليمي والدولي.

ثانياً: المناقشات.

وفي إطـار النشـاطات العلميـة لفـرع الدراسـات الدوليـة، جـرت مناقشـة عـدد مـن الرسـائل والاطاريح، تناولت قضايا سياسية دولية واقليمية تتعلق بتخصص الفرع، ومنها: 


$$
\text { 1- 1 - الرسائل }
$$

أ- رسالة طالب الماجستير عدنان رميض الموسومة السياسة الخارجية لدول مجلس التعاون

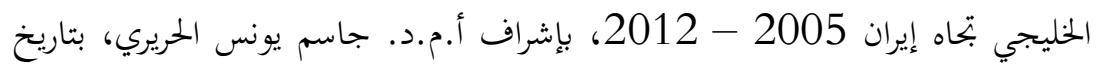

$$
\text { .2014/6/26 }
$$

ب- رسالة طالب الماجستير إيهاب كريم الموسومة العلاقات الايرانية الاوربية من 1979 -

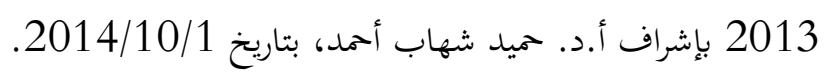

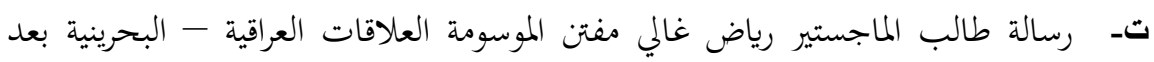

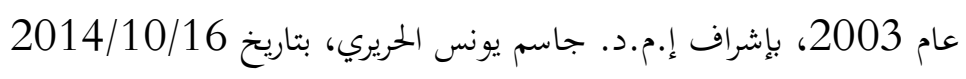

ث- - رسالة طالب الماجستير عباس فاضل عباس الموسومة العلاقات بين روسيا الاتحادية

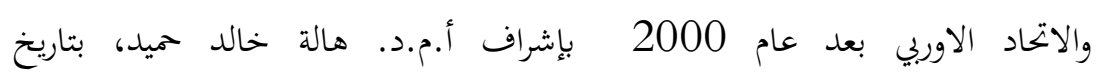

$$
\text { 2014/10/27 }
$$

ج- رسالة طالب الماجستير أحمد خليل أحمد الموسومة أثر القضية الكردية على العلاقات

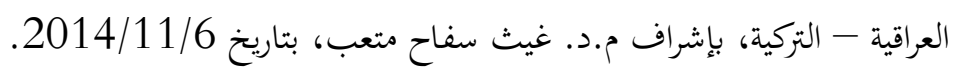

2-

أ- أطروحة طالب الدكتوراه قحطان حسين طاهر الموسومة الأمم المتحدة وإدارة النزاع العراقي

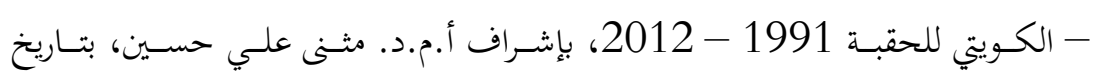

$$
\text { .2014/6/24 }
$$

ب- أطروحة طالب الدكتوراه محمود عبيد محمد الموسومة التنافس الأمريكي الروسي في آسيا

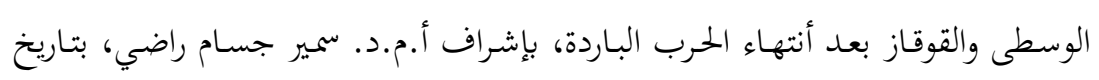

$$
\text { .2014/6/25 }
$$

تـ أطروحة طالب الدكتوراه محسن حساني ظاهر الموسومة السياسة الخارجية الروسية 2000 - 2012، بإشراف أ.م.د. سمير جسام راضي، بتاريخ 2014/8/24. 
ثـ- أطروحة طالبة الدكتوراه حنان علي إبراهيم الموسومة السياسة الخارجية الروسية بتحاه سوريا

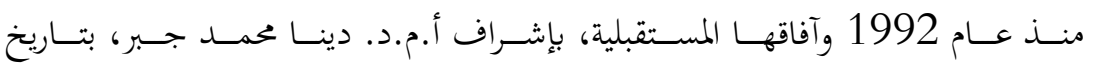

.2014/11/20

\section{ملخص رسالة ماجستير}

عدنان رميض، السياسة الخارجية لدول مجلس التعاون الخليجي تجاه إيران 2005 2012، بإشراف أ.م.د. جاسم يونس الحريري

تركز هذه الدراسة على السياسة الخارجية لدول بجلس التعاون الخليجي بتحاه إيران

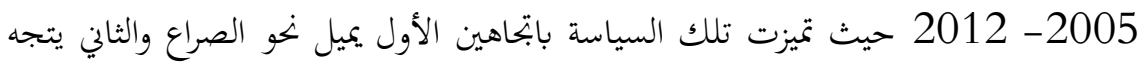

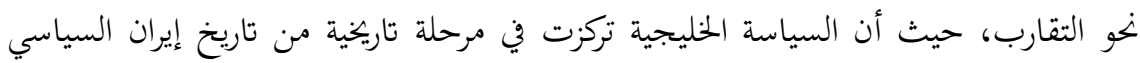

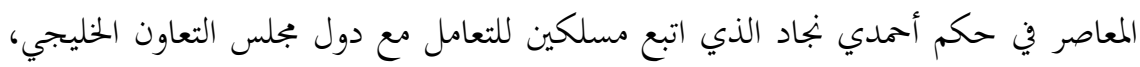

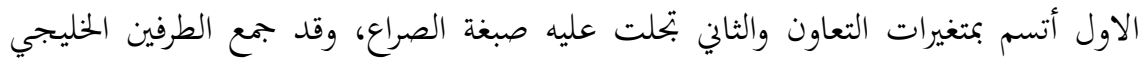

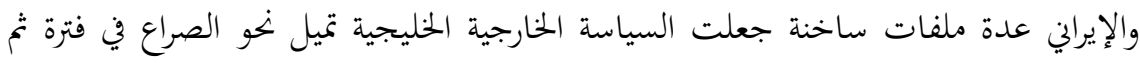
الانتقال لفترة لاحقة إلى مستوى التعاون مع إيران.

\section{وتوصلت الدراسة إلى مجموعة من الاستنتاجات لعل من أبرزها:}

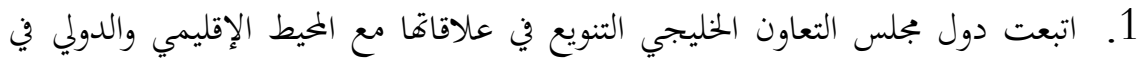

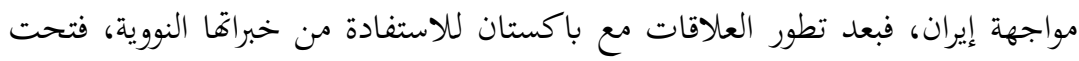

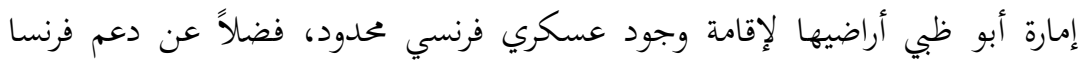
للإمارات في مجال الطاقة النووية. 2. تخشى دول مجلس التعاون الخليجي أن تكون أراضيها ساحة للصدام العسكري بين إيران والولايات المتحدة الأمريكية بسبب تطور الملف النووي الإيراني.

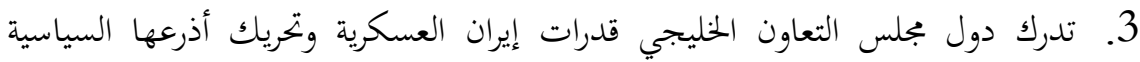
والأمنية في الخنليج في حالة حصول نزاع عسكري في المنطقة خاصة في حالة انحياز دول مجلس التعاون الخليجي للجانب الأمريكي بتحاه إيران. 
4. حاولت دول مجلس التعاون الخليجي أن تتحرك بتحاه إيران بالتنسيق مع حلفاؤها

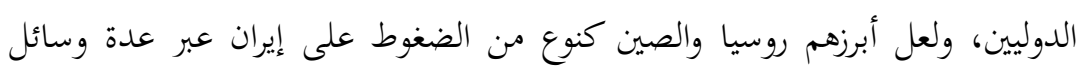

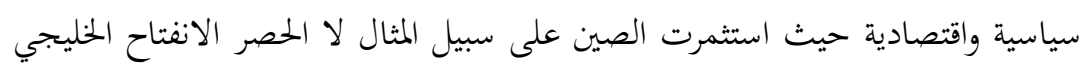
لاستبدال الاعتماد على النفط الإيراني بالنفط السعودي.

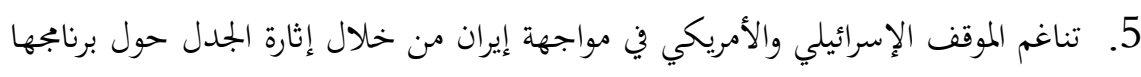

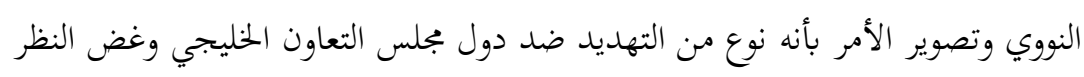

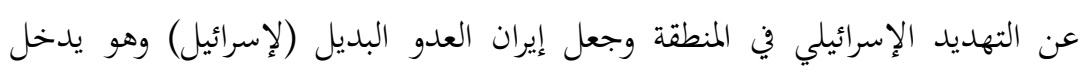

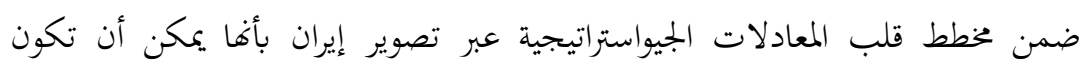

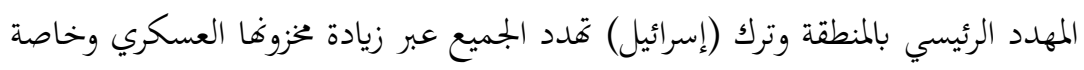
الأسلحة ذات التدمير الشامل، وغض نظر واشنطن عن الدور الإسرائيلي لتفتيت المنطقة

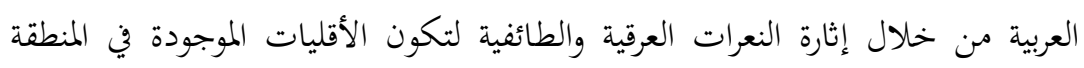

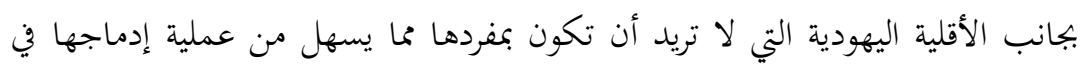
البيئة السياسية هناك عبر مشروع الشرق الأوسط الجديد.

$$
\begin{aligned}
& \text { ملخص رسالة ماجستير } \\
& \text { إيهاب كريم، العلاقات الايرانية الاوربية من } 1979 \text { - } 2013 \\
& \text { بإشراف أ.د. حميد شهاب أحمد. }
\end{aligned}
$$

في عالمنا المعاصر, وأكثر من أي وقت مضى, شهد العالم مرحلة جديدة من التطورات

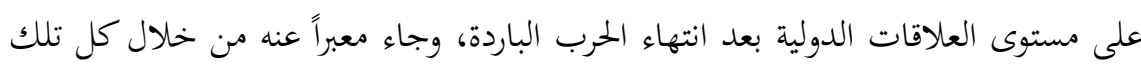

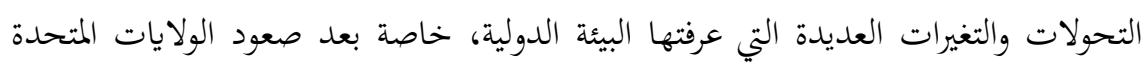
الأمريكية كقوة عظمى ومهيمنة على النسق الدولي ومع تزعمها لهذا النظام الجديد وتفردها

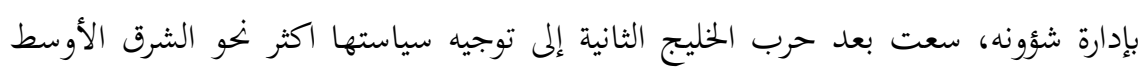

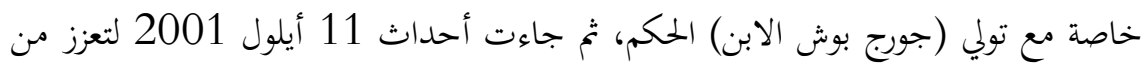

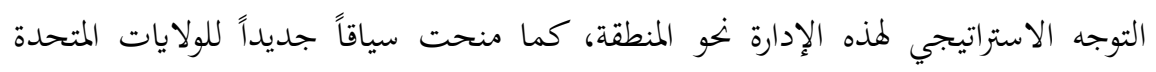

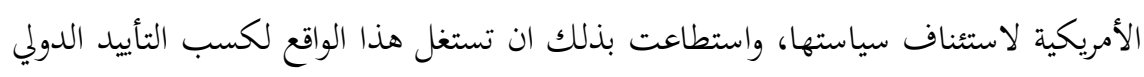

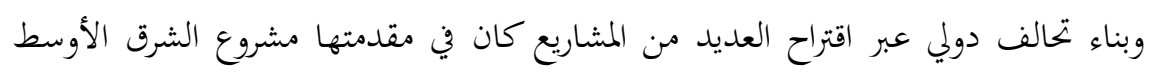


الكبير,وفي هذا الاطار طرحت قضية الدول المارقة المتمثلة بسوريا ,وايران, والعراق ,وليبيا , وكوريا الشمالية , وبدأت حملة مكافحة الإرهاب بأفراده ومنظماته الإرهابية، التي تشمل دولاًا

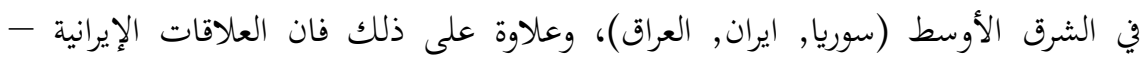

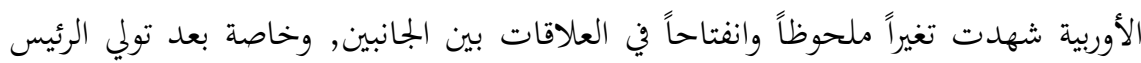

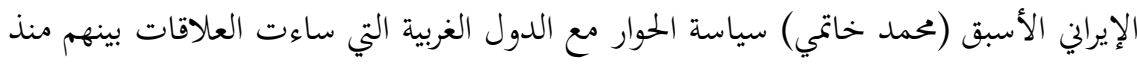

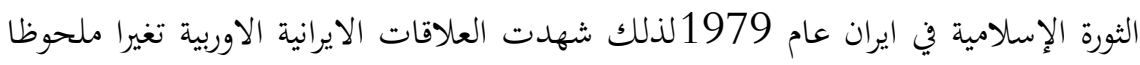

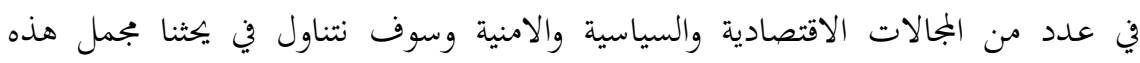

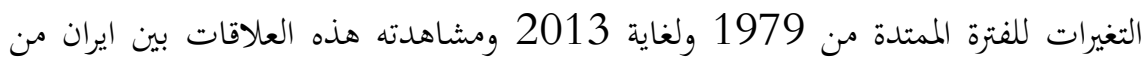
جهة والدول الاوربية من جهة اخرى وماهية المتغيرات التي اثرت على هذه العلاقات.

\section{ملخص رسالة ماجستير}

عباس فاضل عباس، العلاقات بين روسيا الاتحادية والاتحاد الاوربي بعد عام 2000، ملحير المشرف : أ.م.د. هالة خالد حميد

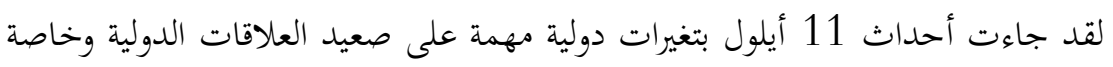

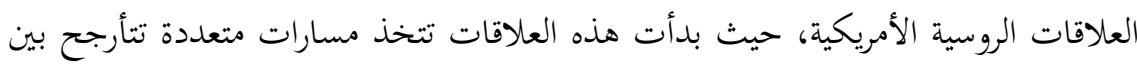
التعاون والتنافس وصولا إلى حرب باردة جديدة على مناطق النفوذ (القديمة الجديدة) في أسيا والشرق الأوسط, وقد طغت على هذه العلاقات التوجهات السياسية لكل من الإدارات

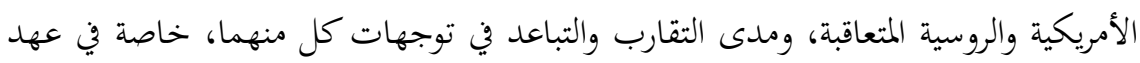
الرئيس الروسي بوتين, وهذه الحقيقة أثرت بشكل كبير على العلاقات الأوربية الروسية التي

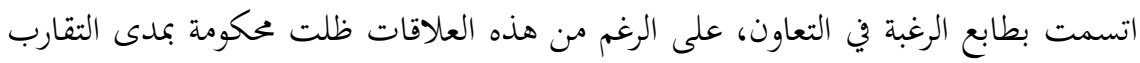

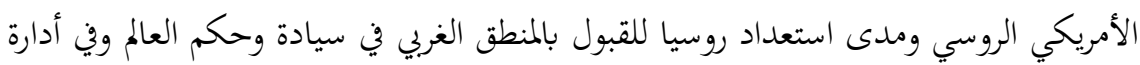

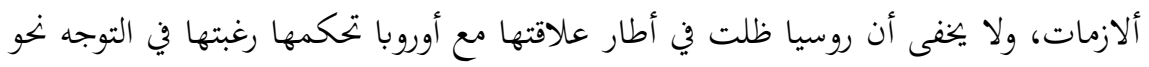
العمق الأوربي والانضمام كعضو في البيت الأوربي الذي تشعر بأخها تنتمي إليه بحكم الانتماء

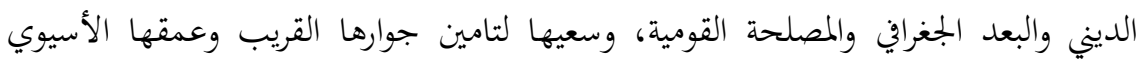

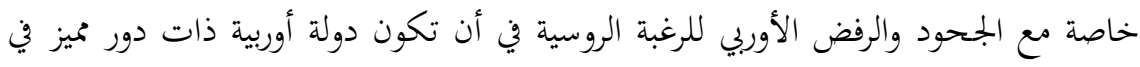


الأمن والاقتصاد الأوربي بسب التخوف الأوربي من الطموح الروسي باستبدال المظلة الأمريكية بمظلة روسية ذات امتدادات أسيوية.

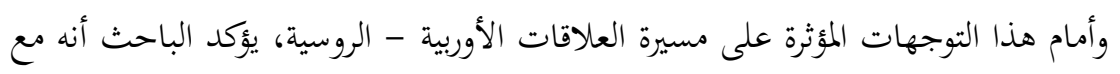

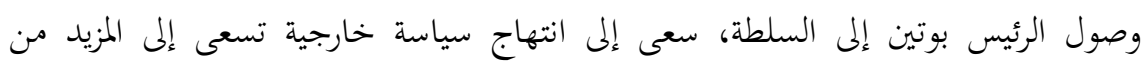

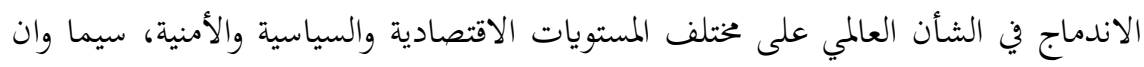

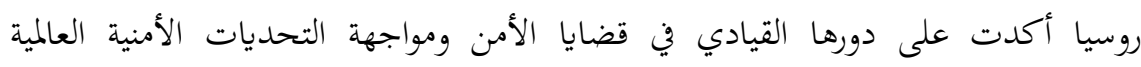

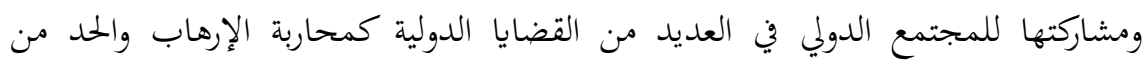

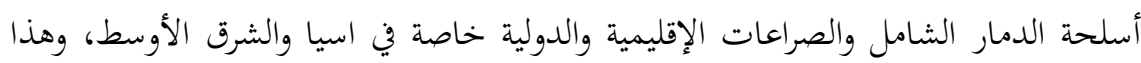

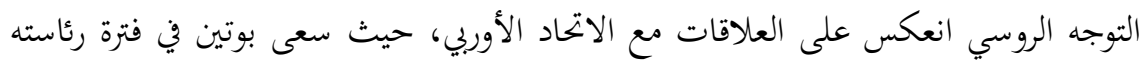

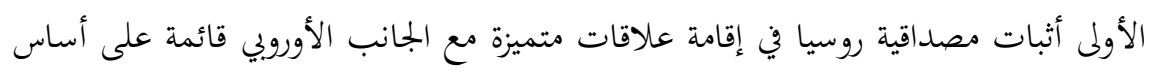
الشراكة، مع الاحتفاظ بالخصوصية الروسية كوها قوة اورو اسيوية.

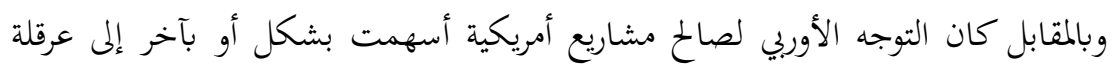

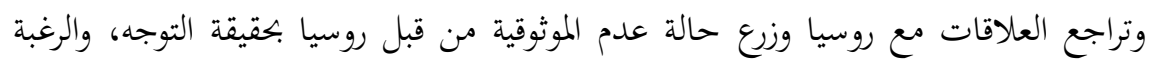

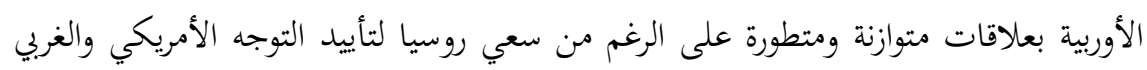

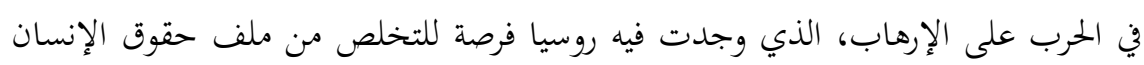

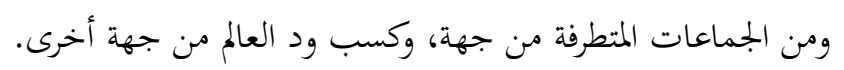

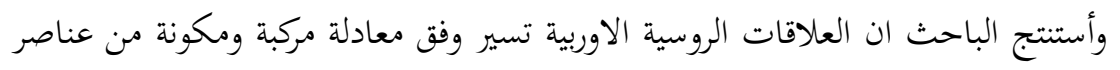

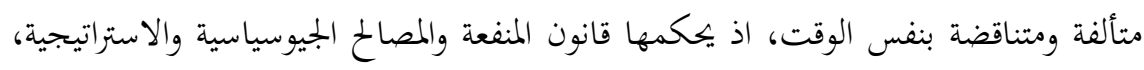

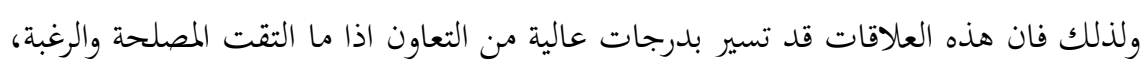

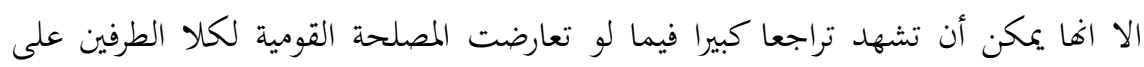

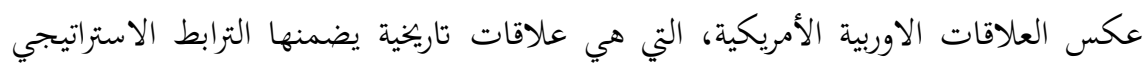
والمعنوي في ثوابت قيادة العالم ورسم السياسة الخارجية. 


\section{ملخص أطروحة دكتوراه}

محمود عبيد محمد، التنافس الأمريكي الروسي في آسيا الوسطى والقوقاز بعد أنتهاء

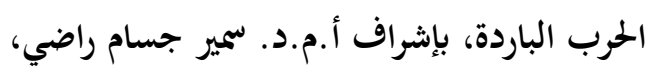

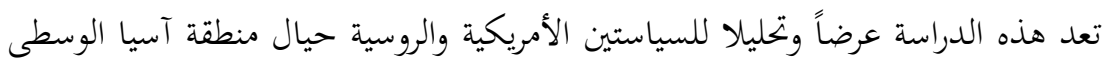

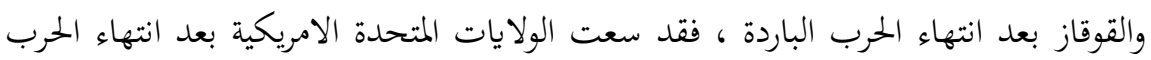

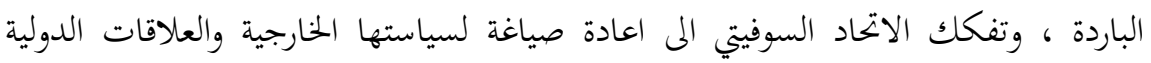
واعادة تعريف مفهوم المصالح الوطنية الامريكية وتوسيعه في ضوء رغبتها في تشكيل النظام

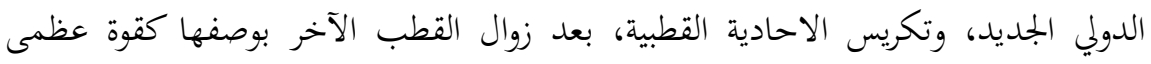

$$
\text { وحيدة في عالم ما بعد الحرب الباردة. }
$$

وفي اطار هذا التوجه، تركز الاهتمام الامريكي على التواجد في العديد مهده من المناطق

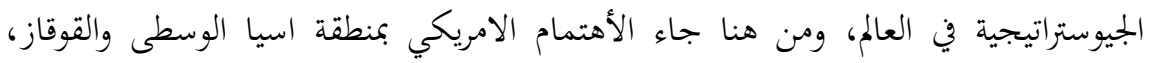

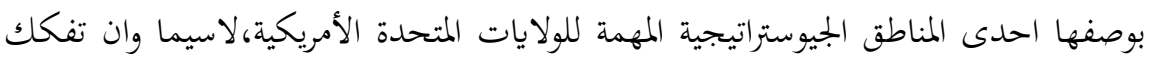

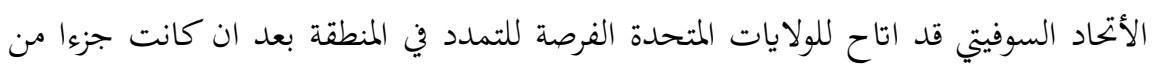

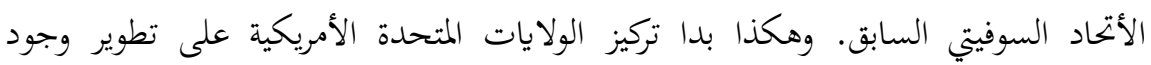
اقتصادي وعسكري مهم في منطقة اسيا الوسطى والقوقالز، وبناء علاقات مشاركة مع دول

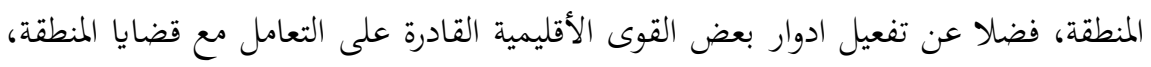
كتركيا وإسرائيل، وذلك في أطار حرص الولايات المتحدة على تامين الاستقرار في الأقاليم

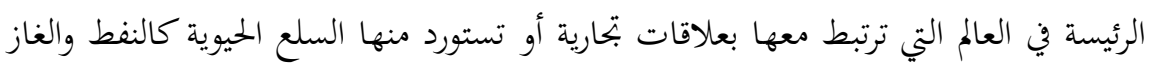

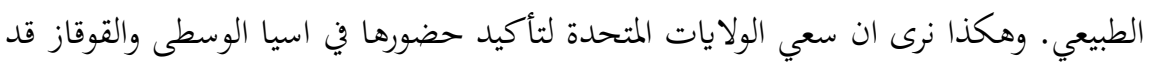

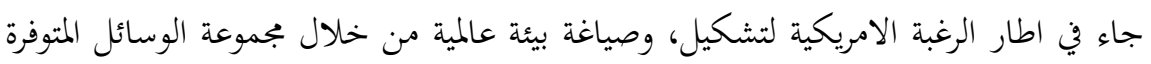

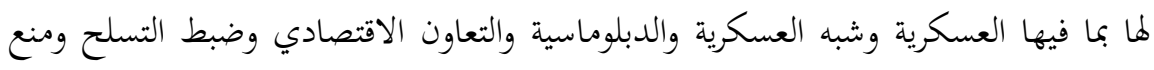

$$
\text { الانتشار ومحاربة الأرهاب في سبيل تعزيز الأمن الأمريكي. }
$$

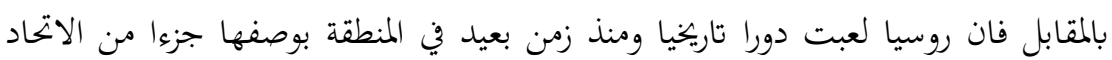

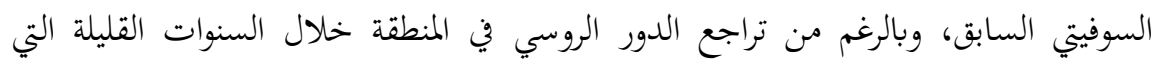

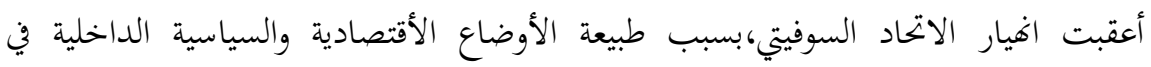


روسيا، الا ان روسيا سرعان ماعاودت تفعيل حضورها في المنطقة، وذلك في أطار سعيها الى

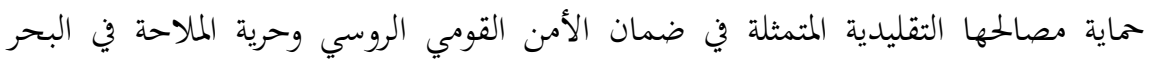

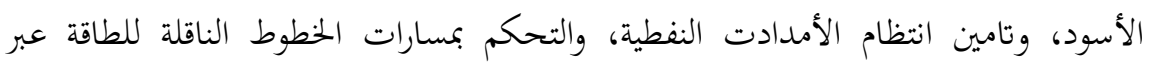

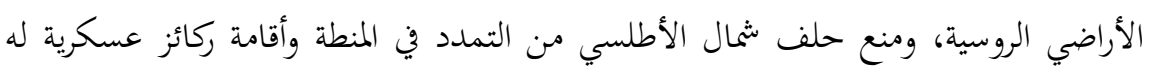

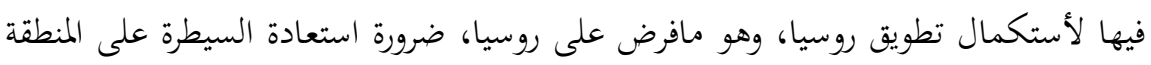

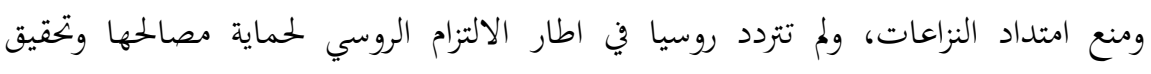

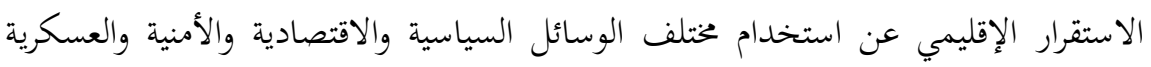
لتحقيق ذلك، وذلك في اطار الاستراتيجية التدخلية الروسية في المنطقة.

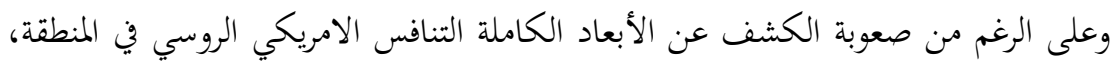

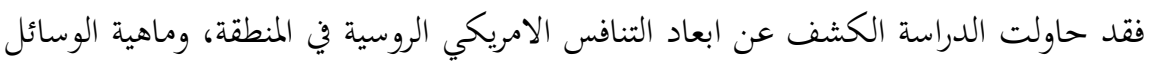

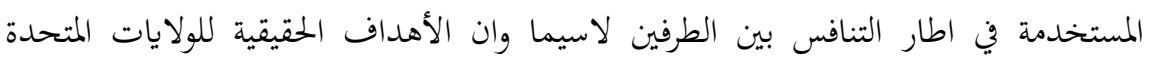

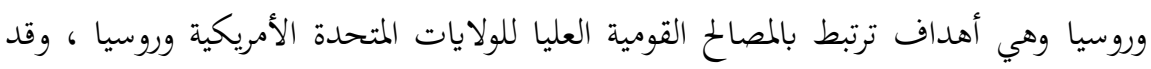

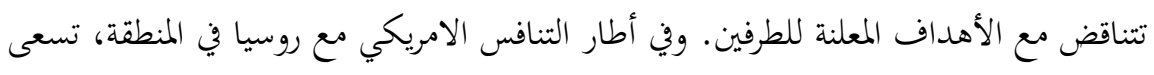
الولايات المتحدة الى تحقيق التعددية السياسية وترسيخ التحول الديمقراطي في المنطقة، وأدماج

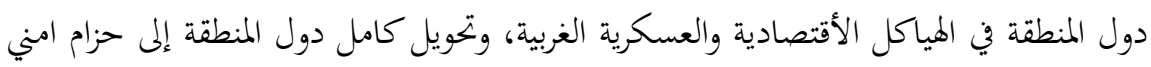

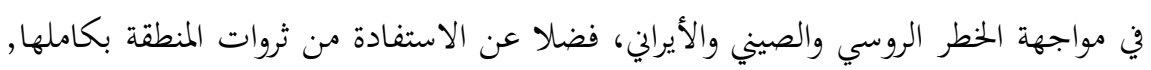

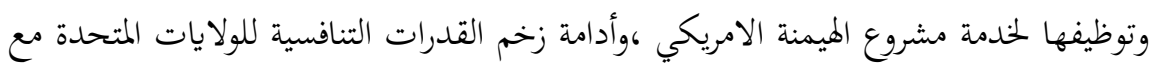

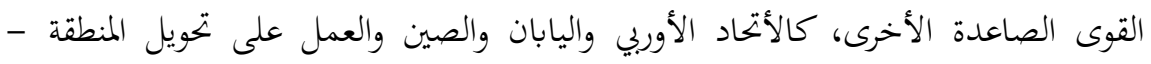

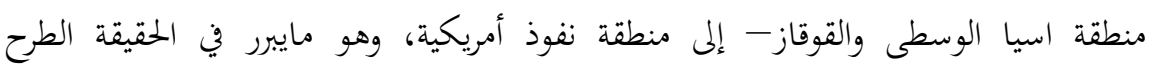

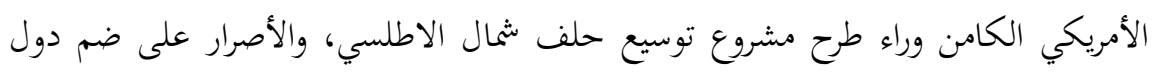

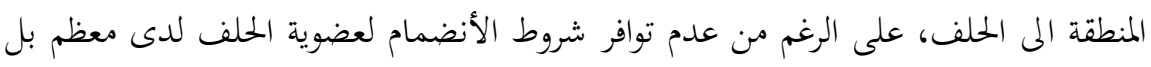
ولجميع دول المنطقة. 


\section{ملخص أطروحة دكتوراه}

قحطان حسين طاهر، الأمم المتحدة وإدارة النزاع العراقي- الكويتي للحقبة 1991 إنوراه

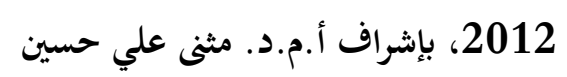

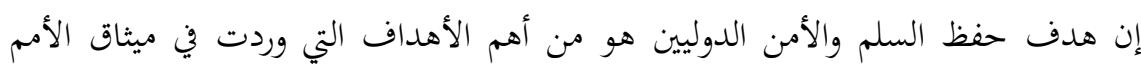

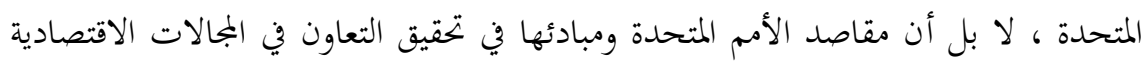

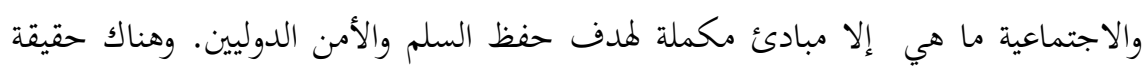
مهمة هي أن سلوك المنظمة الدولية ما هو إلا انعكاس لأوضاع النظام الدولي، وهذه الحقيقة

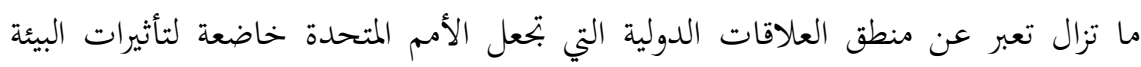

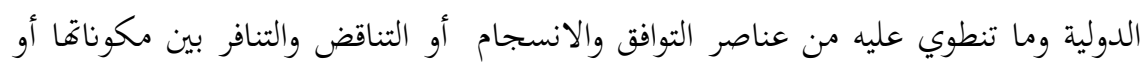
هيمنة قوة معينة على مقدرات النظام الدولي. لقد بتلّت الأفكار الآنفة الذكر في مساعي الأمم المتحدة والجهود التي بذلتها في مواجهة التهات

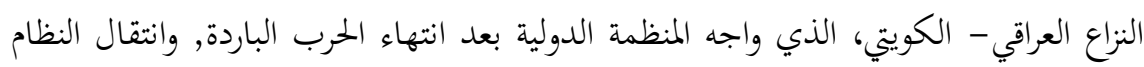

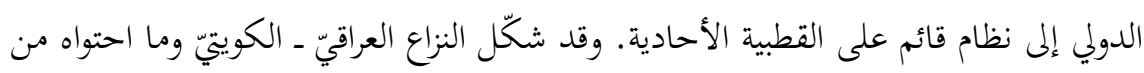

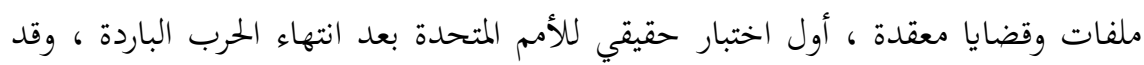

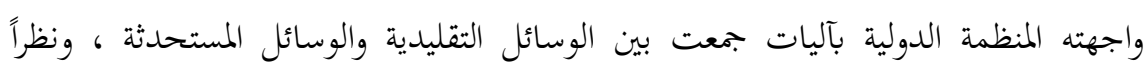

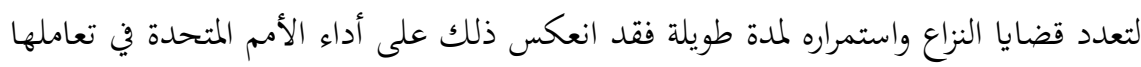

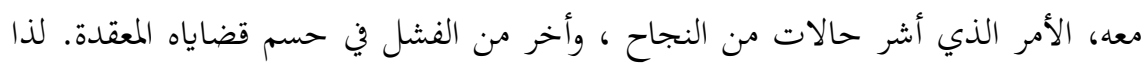

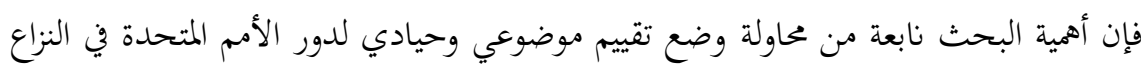

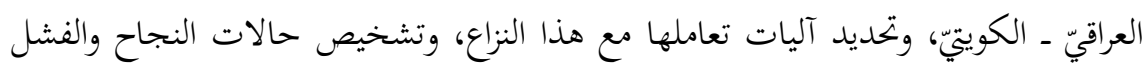

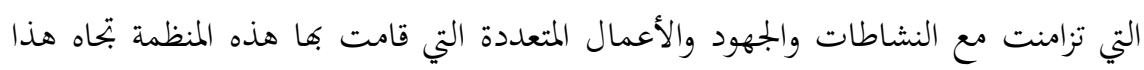

وتحاول هذه الدراسة أن تطرح إشكالية تستند إلى رؤى فكرية عن طبيعة أداء منظمة الأمم

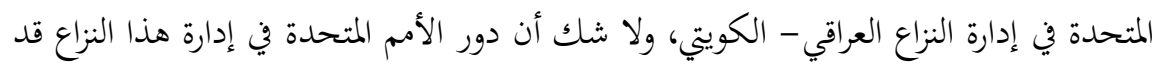

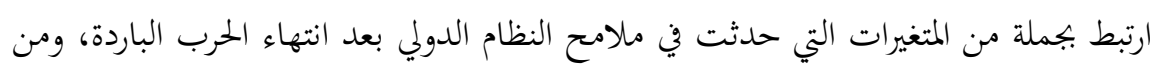

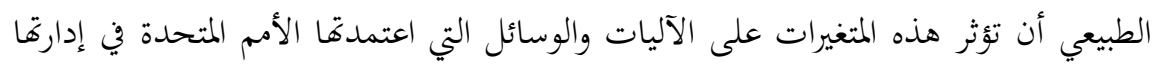


للنزاع بين العراق والكويت، الأمر الذي ينعكس على طبيعة وحجم وقوة أداء هذه المنظمة في معالجة قضايا النزاع العراقي - الكويتي.

\section{ملخص أطروحسـة دكتوراه}

محسن حساني ظاهر، السياسة الخارجية الروسية 2000 - 2012، بإشراف أ.م.د. سمير

\section{جسام راضي}

شهات السياسة الخارجية الروسية بعد انتهاء الحرب الباردة في العام 1991 وتفكك

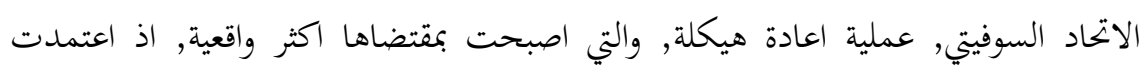

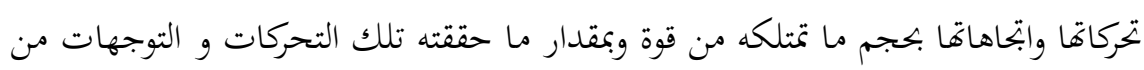
فائدة للمصالح الوطنية الروسية, وفي هذا الاطار سعت روسيا الاتحادية و لاتزال الم تصحيح

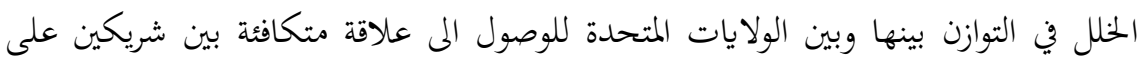

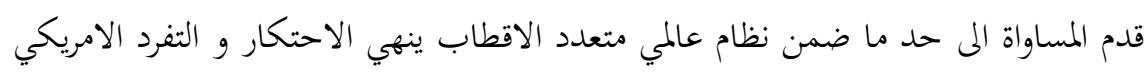

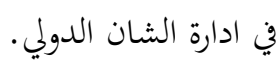
ان السياسة الخارجية لروسيا الاتحادية تنطلق من اسس واقعية براغماتية, وبما ينسجم مع

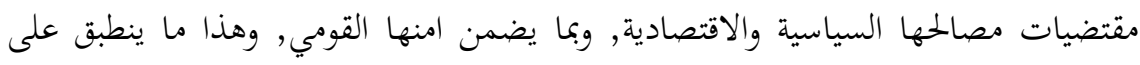

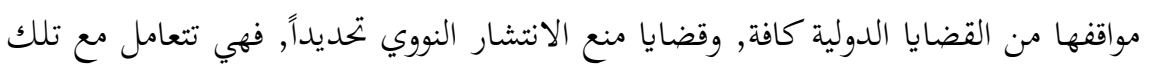

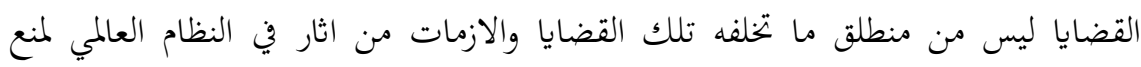

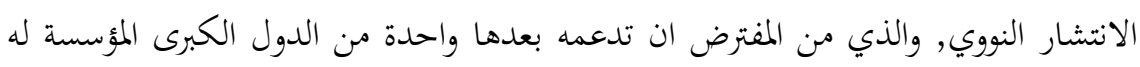
وانما من منظور ما تشكله تلك القضايا من مكاسب خدمة لاهداف سياستها الخارجية. 
ثنانياً: النشاطات العلمية لفرع الفكر السياسي للعام الدر اسي 2014 -

عقد فرع الفكر السياسي ندوتة الفصلية الثانية والموسومة ب(الغرب والقوى السياسية الصاعدة في العالم العربي بعد التغيير) التي ترأسها أ.م.د سعدي كريم سلمان يوم الاثنية الثنين بتاريخ

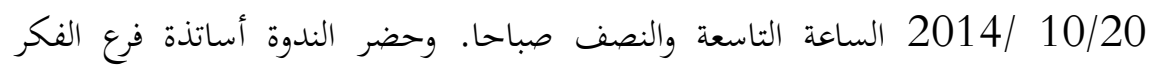

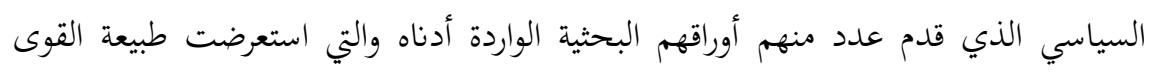

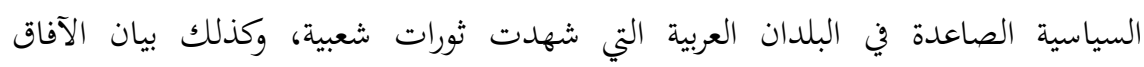

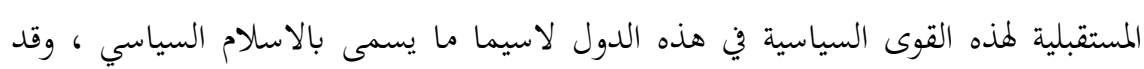

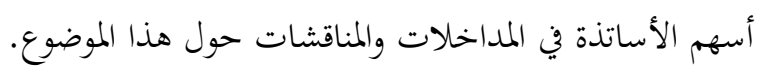

$$
\begin{aligned}
& \text { الاوراق البحثية المقدمة في الندوة : } \\
& \text { 1- أ.م.د تغريد حنون علي : لإحثية المقدمة الندوة: }
\end{aligned}
$$

(الؤية الامريكية والقوى السياسية العربية الصاعدة بعد التغيير).

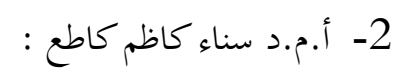

(غياب البعد الاستراتيجي للقوى السياسية الاسلامية العربية بعد التغيير ).

$$
\text { 3- أ.م.د عبير سهام مهدي : (اب البعد الاستراتجي }
$$

(ابعاد التحول في الموقف الامريكي حيال الحركات الاسلامية بعد الربيع

$$
\text { 4- م.د منى حمدي حكمت: العربي) . }
$$

(كيفية تعاطي الفكر الامريكي مع الثورات العببية وعلاقته مع قوى الاسلام

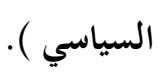

$$
\text { 5- م.د طارق عبد الحافظ عدنان . }
$$

(الاسلام السياسي ودوره المستقبلي ما بعد الثورات العربية المعاصرة ) .

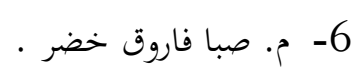

$$
\text { (قوى الغرب وتعاملها مع قوى الربيع العربي ). }
$$




$$
\begin{aligned}
& \text { 7- 7.م احمد عبد الكريم عبد الوهاب : } \\
& \text { (الغرب وصياغة وعي جديد لقوى المنطقة العربية). }
\end{aligned}
$$

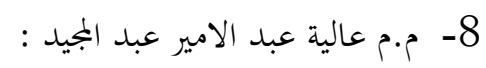

$$
\begin{aligned}
& \text { (موقف الولايات المتحدة الامريكية من الربيع العربي ). }
\end{aligned}
$$

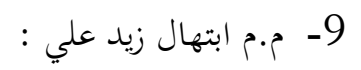

$$
\begin{aligned}
& \text { ( القوى السياسية الصاعدة في العالم العربي بعد التغيير) . }
\end{aligned}
$$

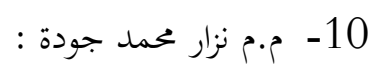

(الهوية الوطنية العراقية : قراءة في توجهات الاحزاب الاسلامية العراقية).

$$
\begin{aligned}
& \text { توصيات الندوة : } \\
& \text { وقد خرجت الندوة بعدد من التوصيات من اهمها : }
\end{aligned}
$$

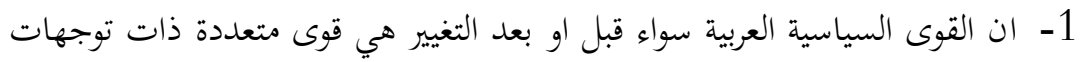

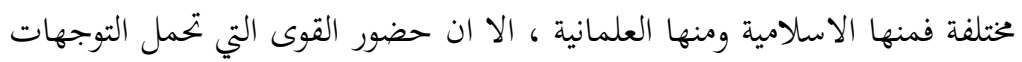

$$
\text { الاسلامية (الاسلام السياسي) اكثر فاعلية من غيرها. }
$$

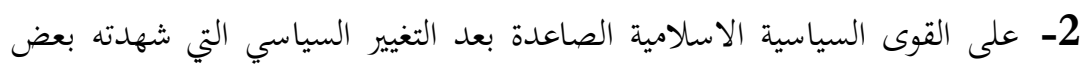

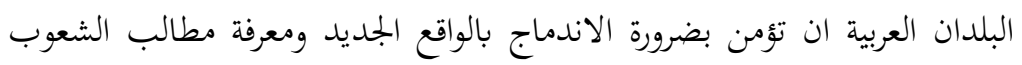

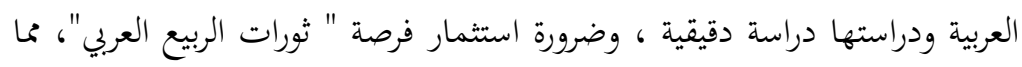

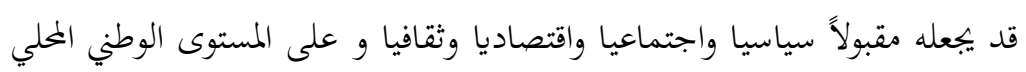

$$
\text { والإقليمي والدولي. }
$$

3- ضرورة صياغة رؤية فكرية واستراتيجية وخطاب سياسي يواكب التغيرات التي تمر بها

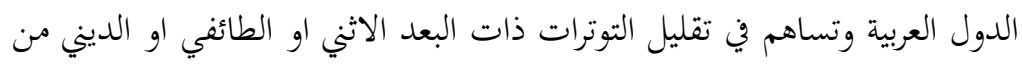

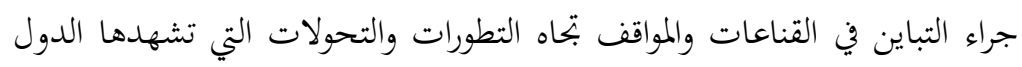

$$
\text { العربية . }
$$


في إطار النشاطات العلمية لفرع الفكر السياسي جرت مناقشة عدد من الرسائل والاطاريح تناولت قضايا سياسية متنوعة تخص فرع الفكر السياسي منها :

أ- الرسائل :

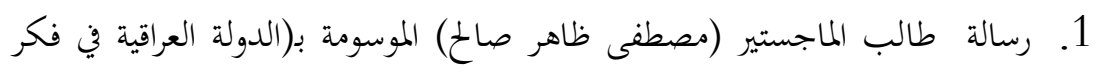

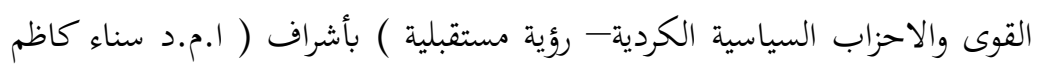
كاطع ) بتاريخ 2014/5/14.

2. رسالة طالب الماجستير (محمد فرحان مذكور) والموسومة بـ(روجية غارودي: دراسة

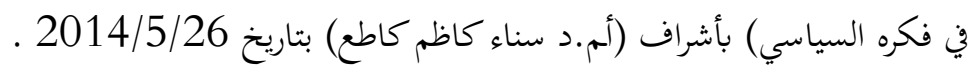
3. رسالة طالب الماجستير (عمر حمدان جبوري) والموسومة ب(الطروحات الفكرية الدولة

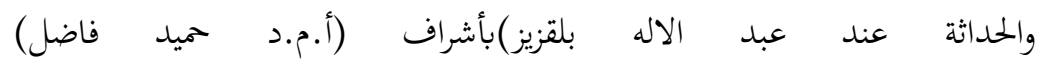
2014/10/19. بتاريخ 4. رسالة طالبة الماجستير (الاء محمد عبد الخالق) والموسومة بـ(الدولة الفلسطينية في الفكر الاسرائيلي)بأشراف (أ.م.د. حميد فاضل حسن) بتاريخ

5. رسالة طالبة الماجستير (دلال حميد عطية) والموسومة ب(المراجعات الفكرية للحركات

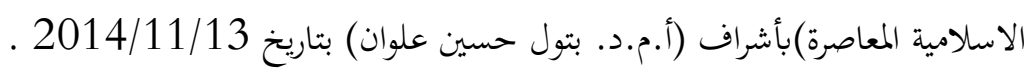

ب- بـ الأطاريح :

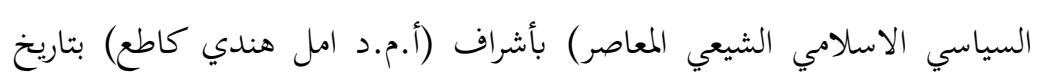
.2014/6/23 2- اطروحة طالب الدكتوراة (محمد هاشم رحمة) والموسومة بـ(البعد السياسي للاستشراق

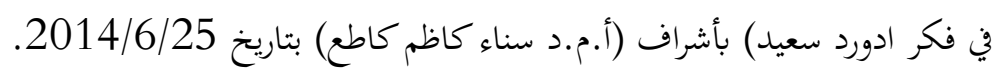

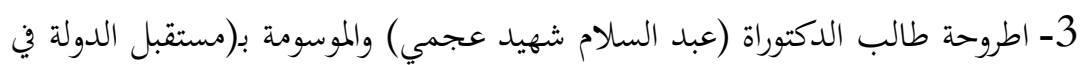

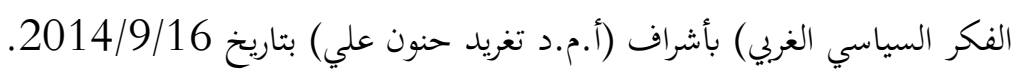


4- اطروحة طالب الدكتوراة (حسن عوده ابو الهيل) والموسومة ب(اسس الطبقة الوسطى

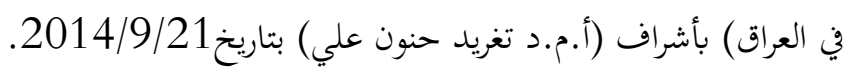

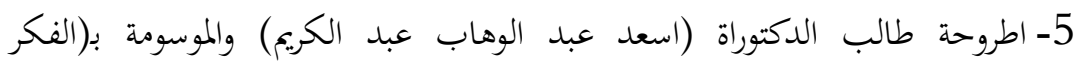

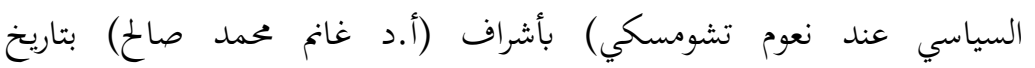

$$
\text { .2014/10/16 }
$$

6- اطروحة طالب الدكتوراة (علي عبد العزيز ميززه) والموسومة بـ(الديمقراطية والامن

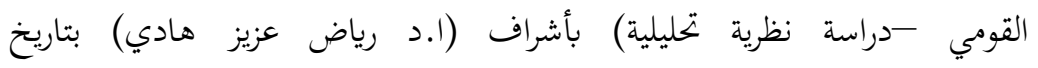

$$
\text { .2014/11/11 }
$$

\section{ملخص رسالة ماجستير}

ناقش طالب الماجستير مصطفى ظاهر صالح رسالثه الموسومة (الدولة العراقية

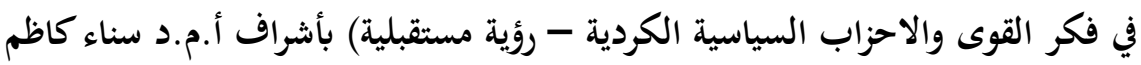

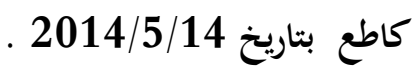

و تأتي أهمية هذه الدراسة من أن رؤية القوى والأحزاب السياسية الكُردية لمستقبل الدولة

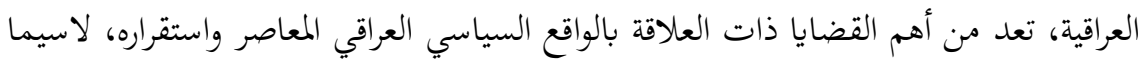

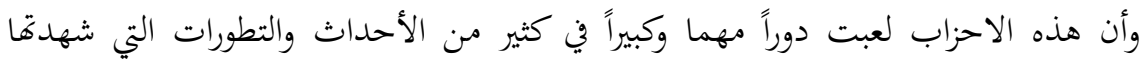
الساحة السياسية العراقية، وعلى هذا الأساس توزعت هيكلية الدراسة على ثلاثة فصول,

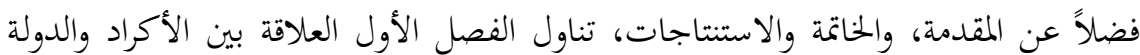

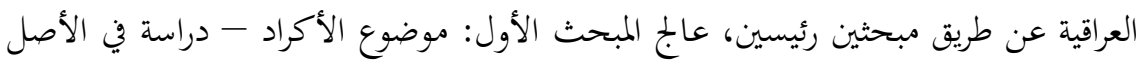

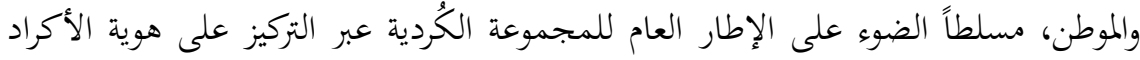

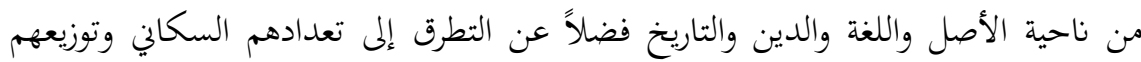

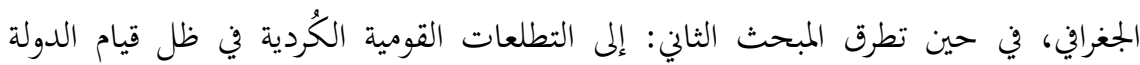

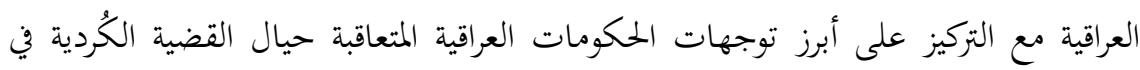

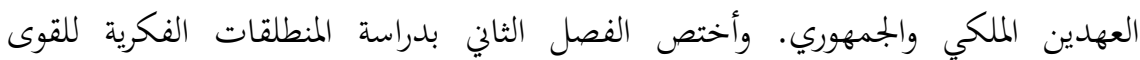

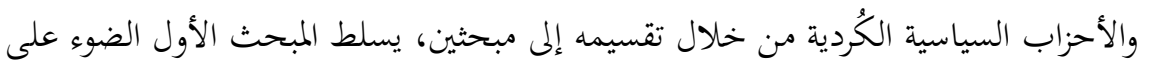


نشأت وتطور القوى والأحزاب السياسية الكُردية ذات التوجهات العلمانية مع التركيز على

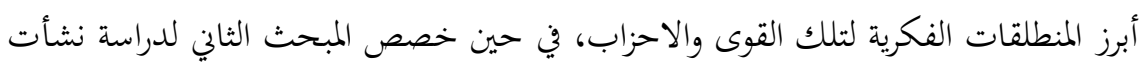
وتطور القوى والأحزاب السياسية الكُردية ذات التوجهات الإسلامية مسلطاً الضوء على ألى أبرز

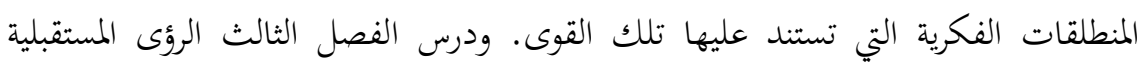

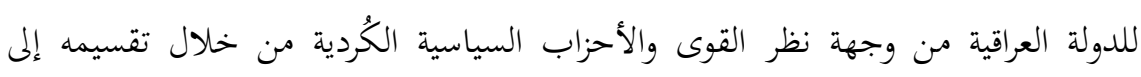

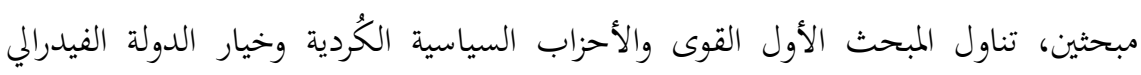

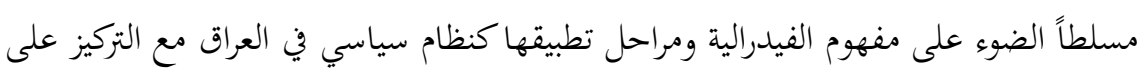

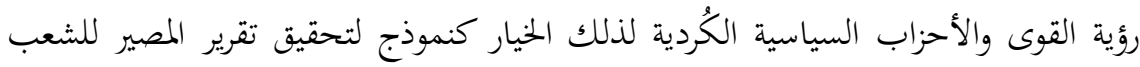

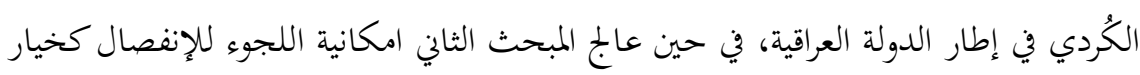

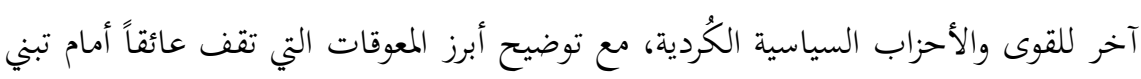
هذا الخيار.

\section{ملخص رسالة ماجستير}

ناقش طالب الماجستير محمد فرحان مذكور رسالثه الموسومة (روجيه غارودي:

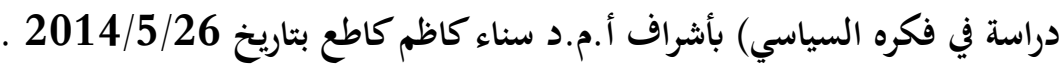

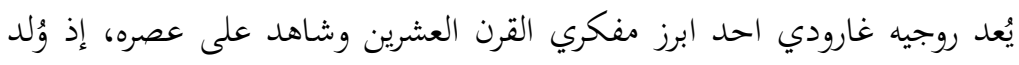

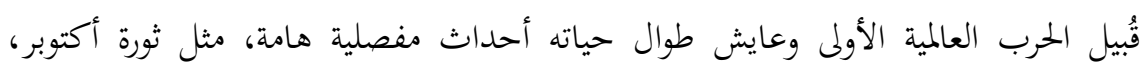

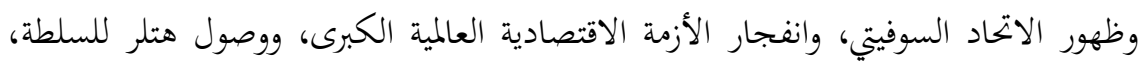

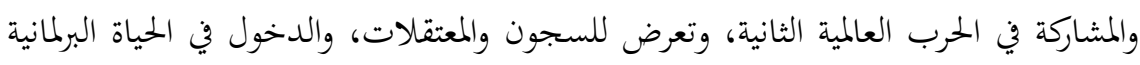

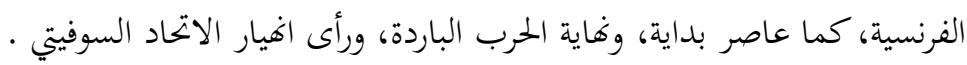

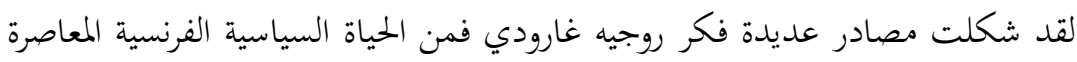
والحياة الاجتماعية والاقتصادية الفرنسية؛ فضلاً عن الحياة الفكرية الفرنسية المعاصرة إلى على الفياة

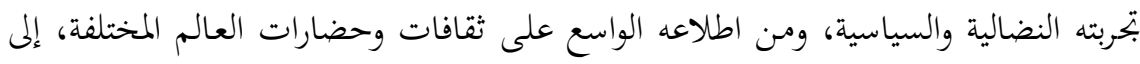

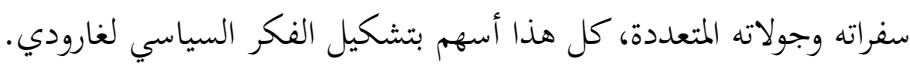

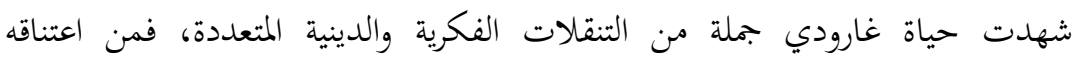

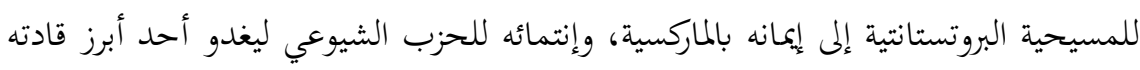


ومنظريه، لتشهد من تََّّ حياته مرحلة مراجعة الماركسية التي أمن بها، ليكمل ما قد بدأه قبل

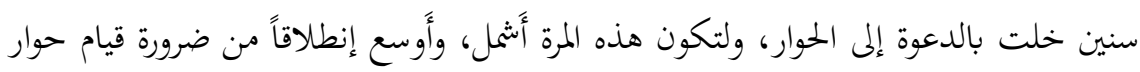

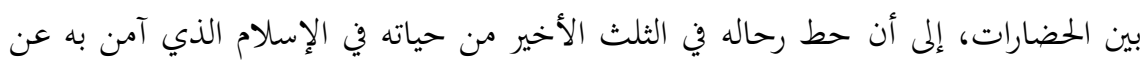
قناعة تامة؛ لأنهُ أجاب عن أسئلة حياته الكبرى المتمثلة في وحدة الإيمان وبالبحث عن الإنه الغايات، بحسب وجهة نظر روجيه غارودي.

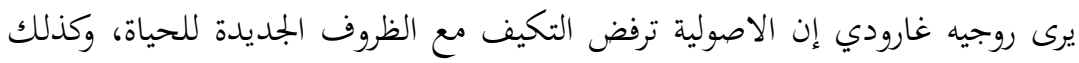

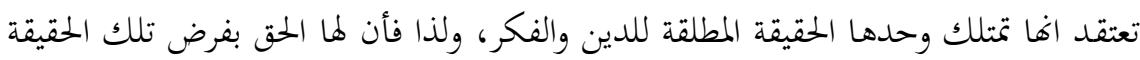

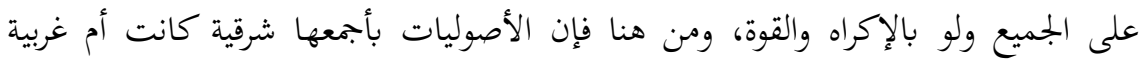

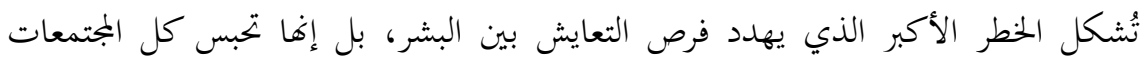

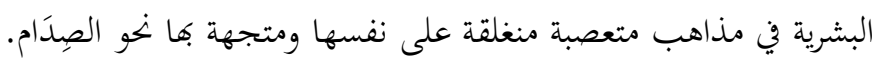
ملخص رسالة ماجستير

ناقش طالب الماجستير عمر حمدان جبوري رسالته الموسومة (الطروحات الفكرية الدولة

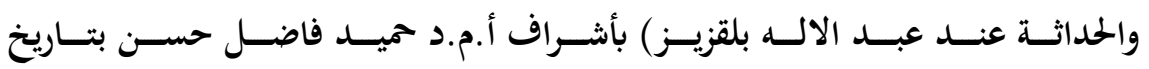
.2014/10/19

يتطلب قيام الحداثة العربية قيام الدولة الوطنية، وقيام الدولة الوطنية العربية يعني قيام

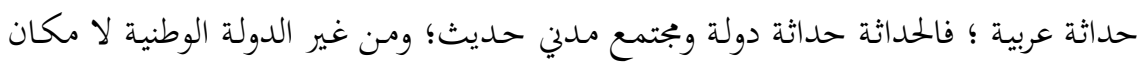

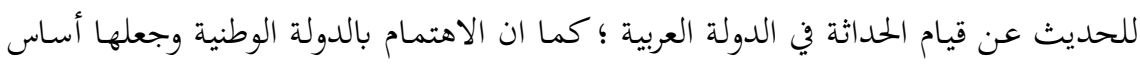

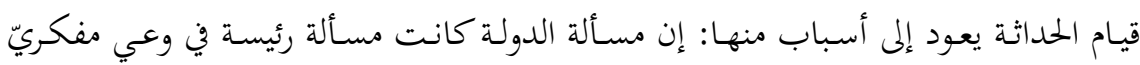

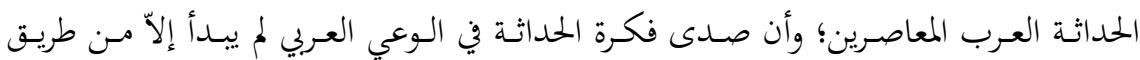

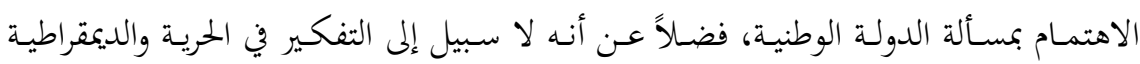

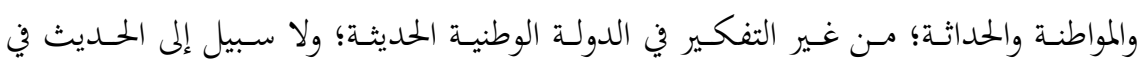

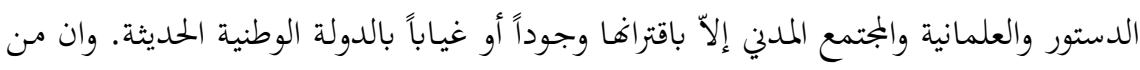
الصعب تصنيف شخصية كشخصية عبد الإله بلقزيز ضمن نسق فكري واحد، وجعله أسيراً

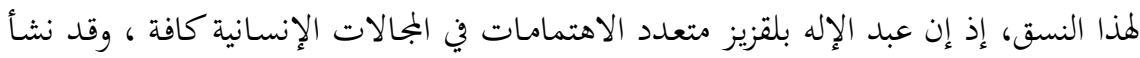

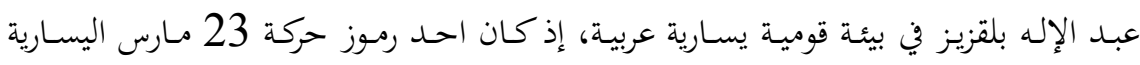


القومية في المغرب، إذ نشأ في بيئة طغت عليها سيطرة الحركة الوطنية المغربية، ونجد تأثير هذه

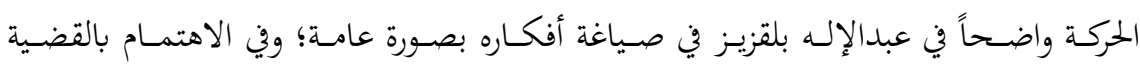
الفلسطينية بشكل خاص.

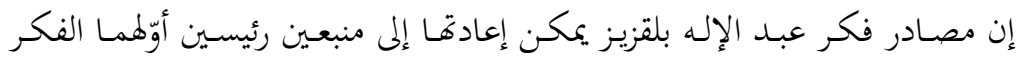

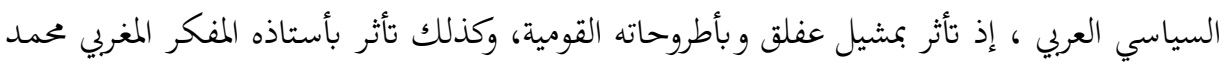

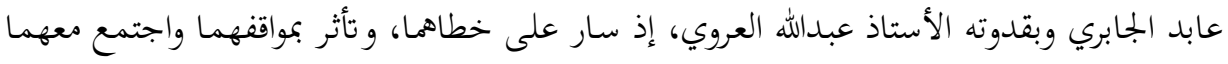

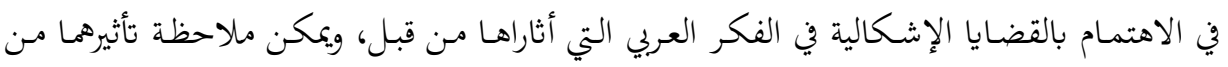

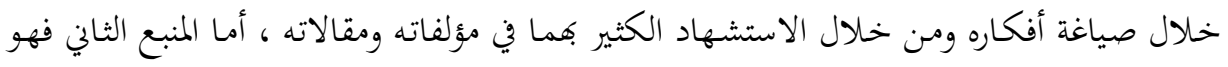

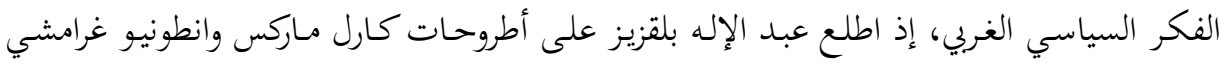

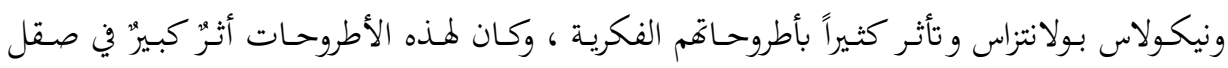

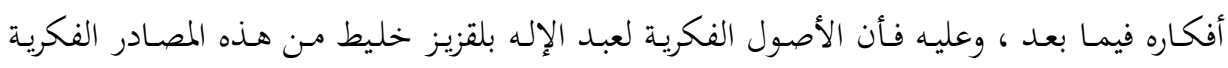
العربية والغربية.

\section{ملخص رسالة ماجستير}

ناقشت طالبة الماجستير الاء محمد عبد الخالق رسالتها الموسومة (الدولة الفلسطينية في ماتسير

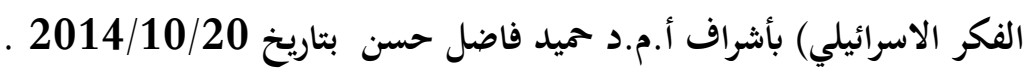

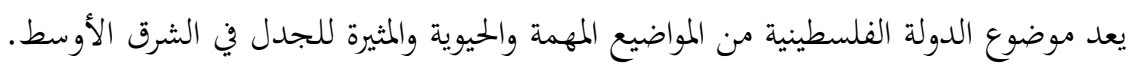
وجاءت هذه الرسالة لتتناول هذا الموضوع منطلقة من رؤى وتصورات الفكر الإسرائيلي

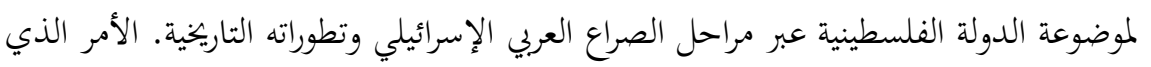

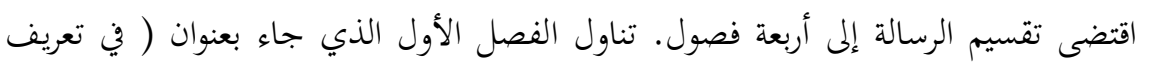

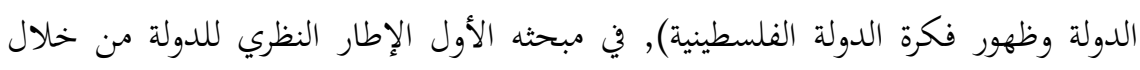

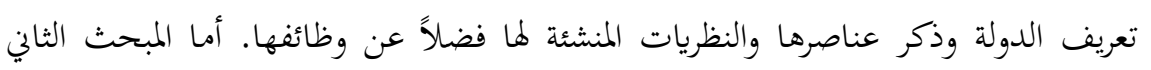

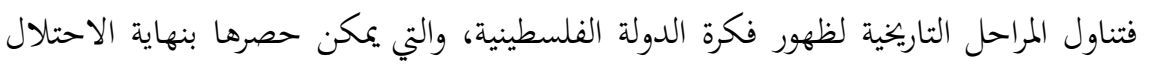

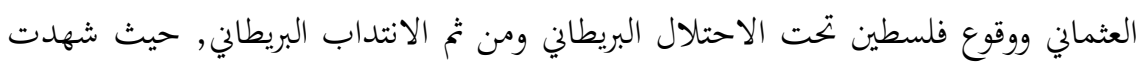

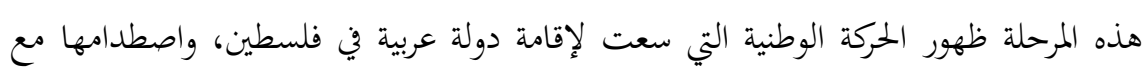


المشروع الصهيوني الأمر الذي اضطر سلطات الانتداب إلى طرح مشروع تقسيم للبلاد, يتضمن حل الدولتين، والذي تبنته الأمم المتحدة عام 1947.

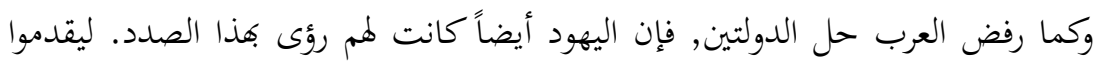

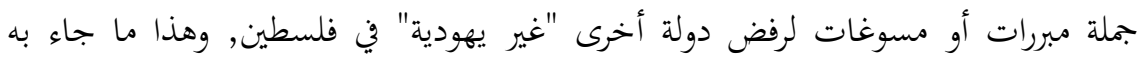

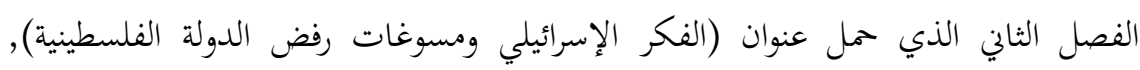

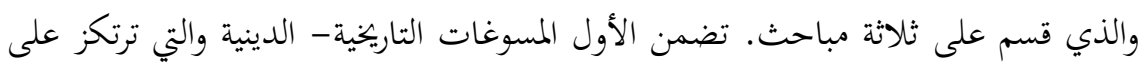

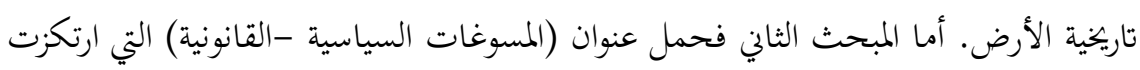

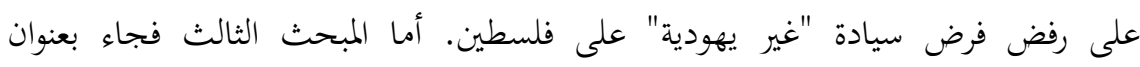

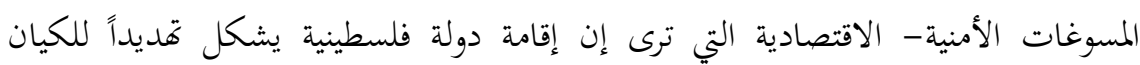

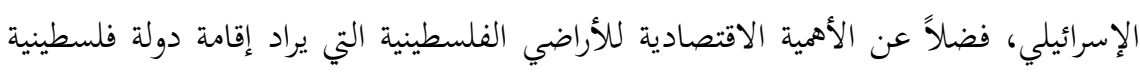

وحمل الفصل الثالث عنوان الفكر الإسرائيلي وقبول الكيانية الفلسطينية, وجاء فيمبحثين.

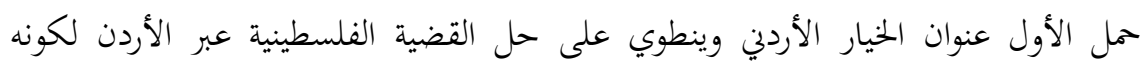

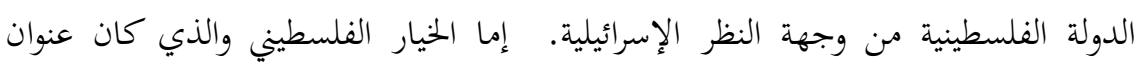
المبحث الثاني, فكان يتضمن إشراك الفلسطينيين في الحل دون اللجوء للأردن.

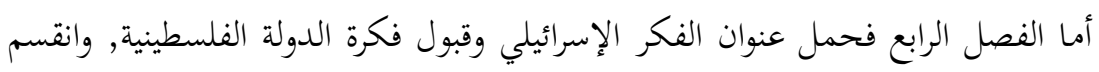

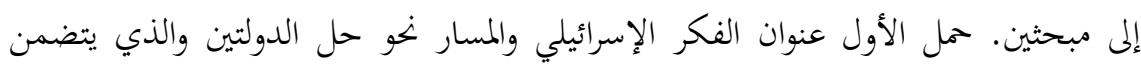

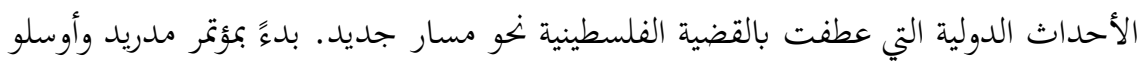

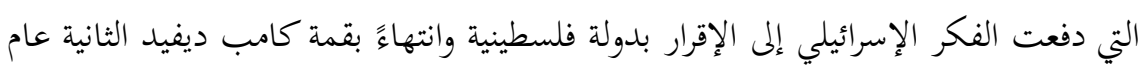
2000. أما المبحث الثاني وعنوانه واقع ومستقبل الدولة الفلسطينية في الفكر الإسرائيلي، الإني،

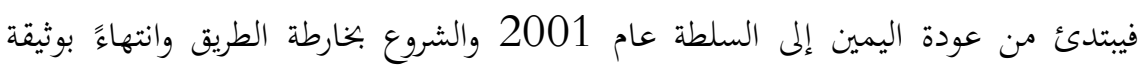
الإطار الإستراتيجي التي قدمت عام 2013, ومن ومن ثم الاستشراف المستقبلي للفكر

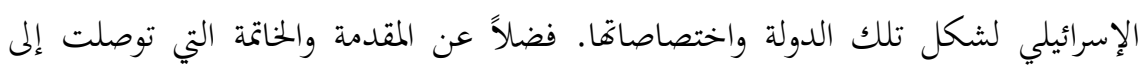

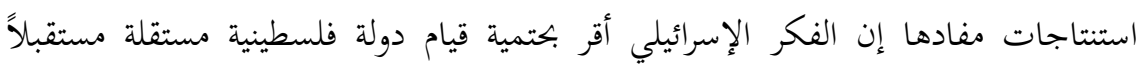
ولكن دون سيادة كاملة، سيما في المجال الأمني. 


\section{ملخص رسالة ماجستيز}

ناقشت طالبة الماجستير دلال حميد عطية رسالتها الموسومة (المراجعات

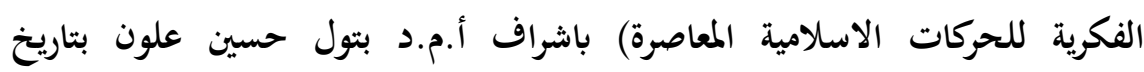
2014/11/13

كانت دوافع واسباب المراجعات الفكرية للحركات الاسلامية المعاصرة متعددة منها ما

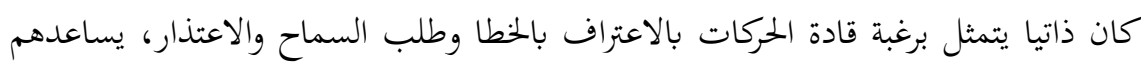

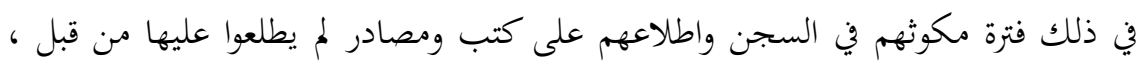

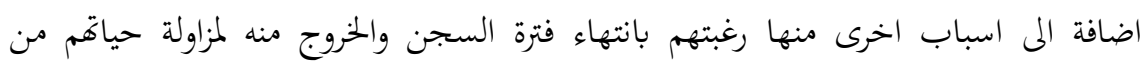

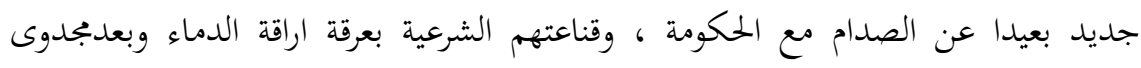

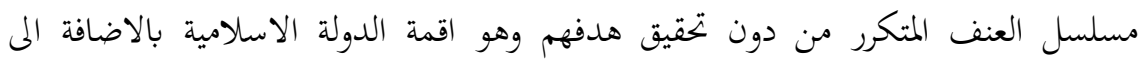

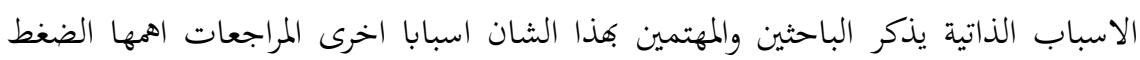

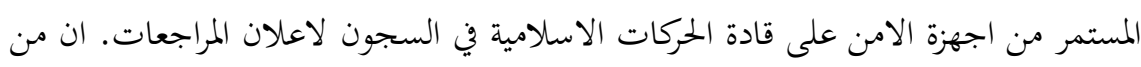

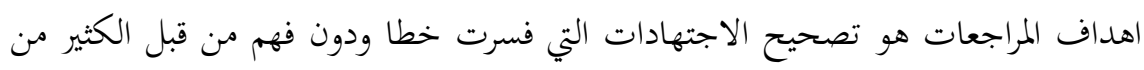

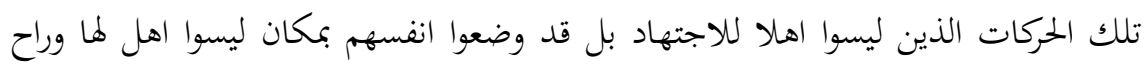

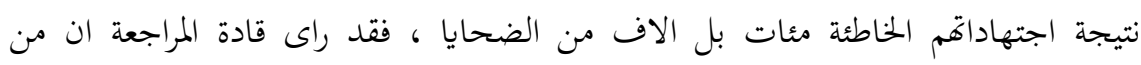

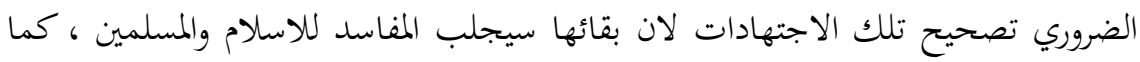

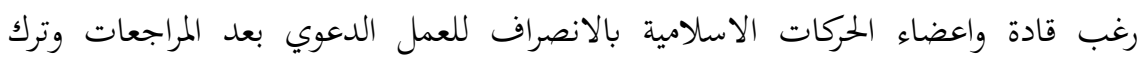
السياسية .

تعرضت عملية المراجعات الى رفض قاطع من قبل عدد من قادة واعضاء الحركات

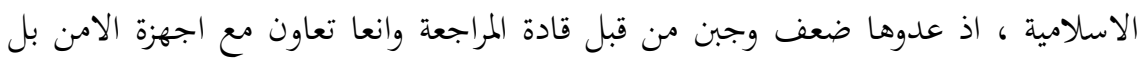

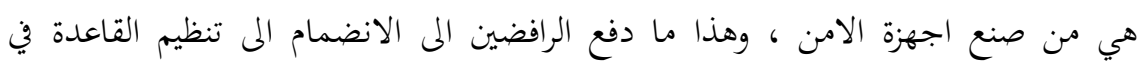

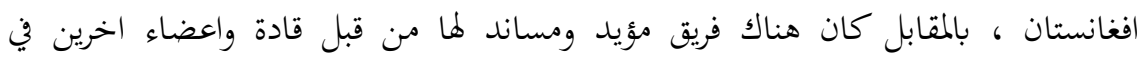


الحركات الاسلامية ايدها وباركها وراى اها السبيل القويم وانه لا جدوى من العنف والعنف المضاد لان الضحية هم ابناء الاسلام .

ان عملية المراجعات برؤية مغايرة للحاكمية عما كانت عليه الحركات الاسلامية

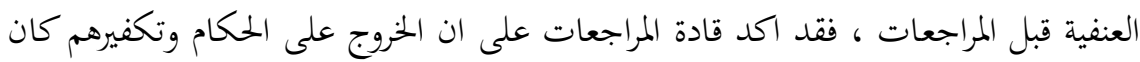

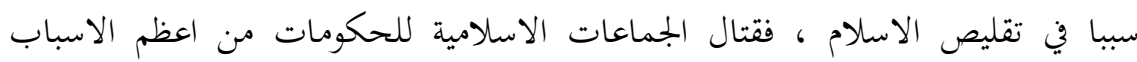

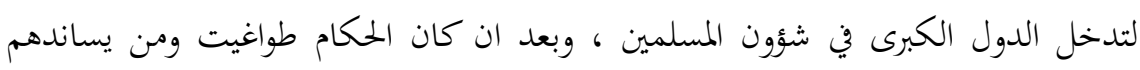

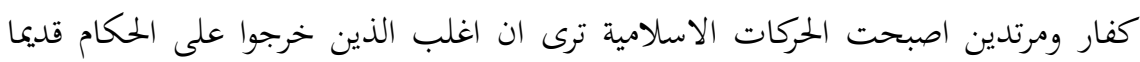

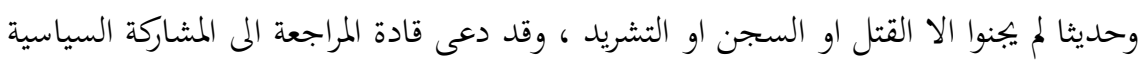

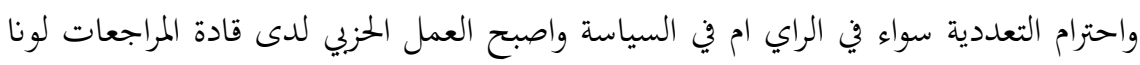

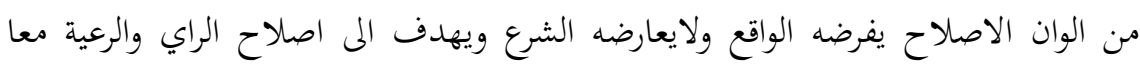

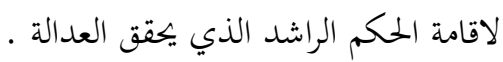

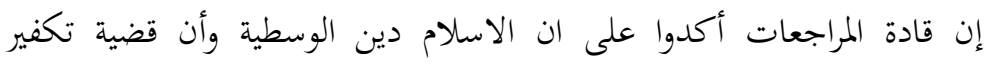

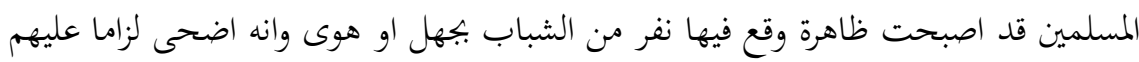

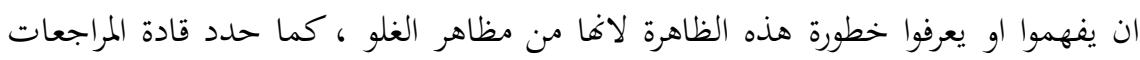

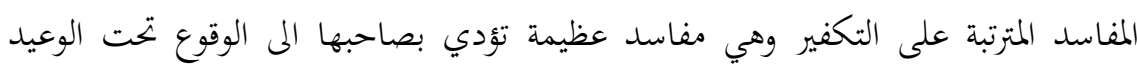

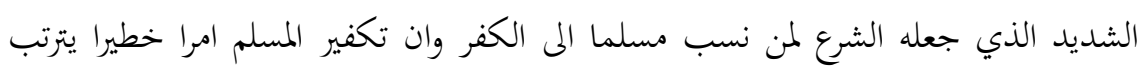

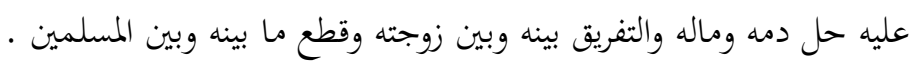

\section{ملخص اطروحة دكتوراه}

ناقش طالب الدكتوراه محمد ابراهيم فلفل اطروحته الموسومة (نظرية ولاية

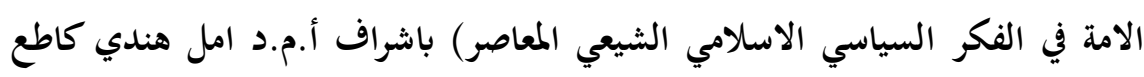
2014/6/23 بتاريخ

انطوت دراسة (نظرية ولاية الأمة)، على أربعة فصول، بكثت في أدبيات الفكر

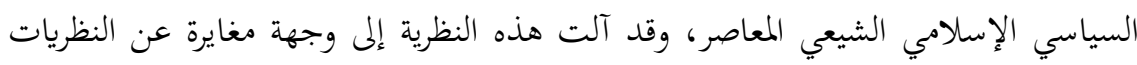

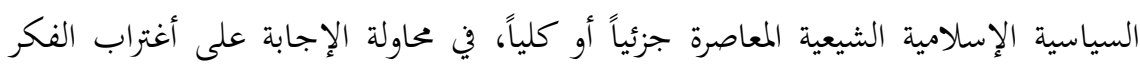

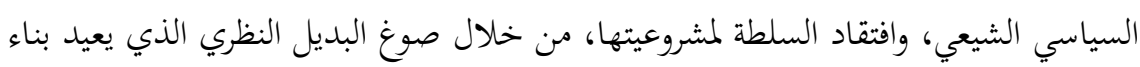


السلطة الشرعية، وتقويم الاختلال الفكري الذي تسبّبت به السلطة الغصبية، وتعويض الفراغ

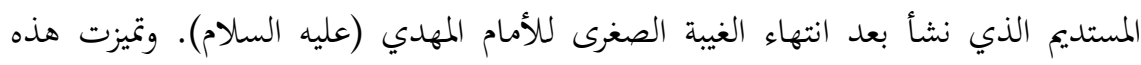

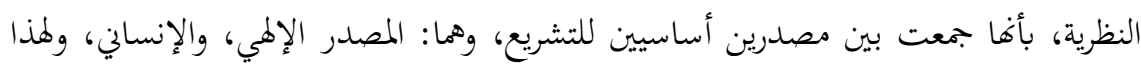
يمكن القول بصحة الفرضية التي أنطلقت منها دراستنا، وهي بأن إشكالية النظرية تتفرع منها

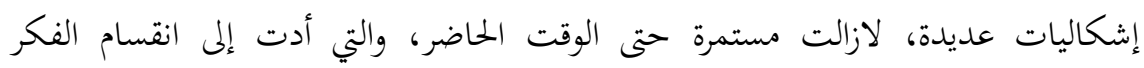

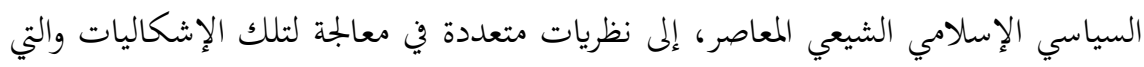

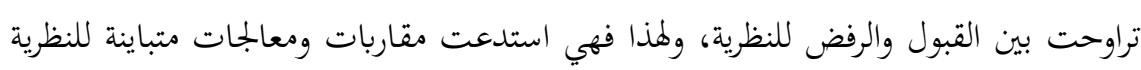

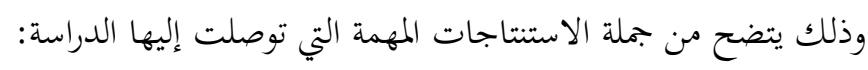

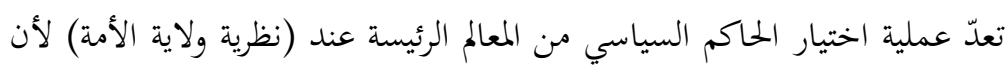

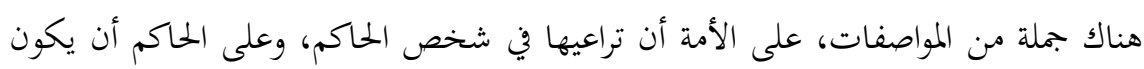

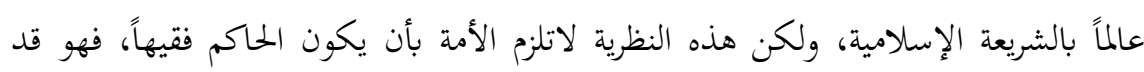

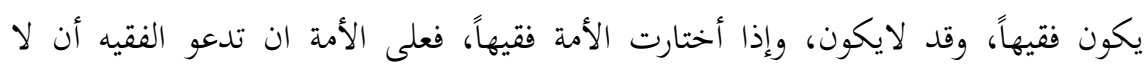

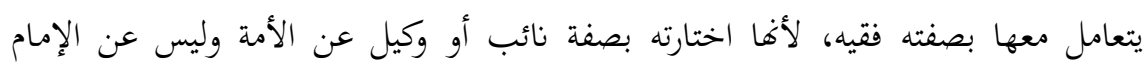

$$
\text { المعصوم (عليه السلام). }
$$

إن قيادة الحكم هي أهم موقع في الأمة وأخطره، لذا يجب أن تكون في غاية النزاهة

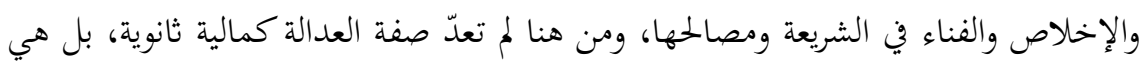

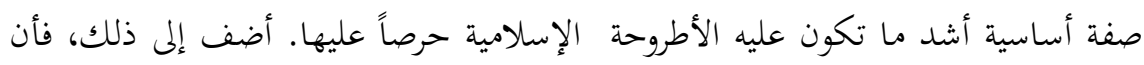
صفة الكفاءة أيضا تعدّ صفة أساسية وضرورية وملازمة للحاكم في (نظرية ولاية الأمة)، فهو الألها العادل الخبير بشؤون الأمة السياسية والمتصدي للدفاع عنها، وعن عقيدةا، والأقوى في إدارة أمورها.

\section{ملخص اطروحة دكتوراه}

ناقش طالب الدكتوراه عبد السلام شهيد عجمي اطروحته الموسومة (مستقبل

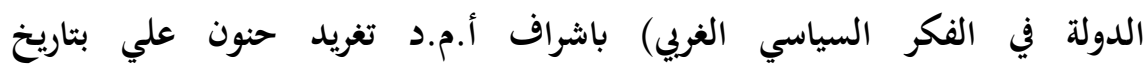


ان نتاجات الفكر السياسي الغربي التي سلطت الضوء على استشراف مستقبل

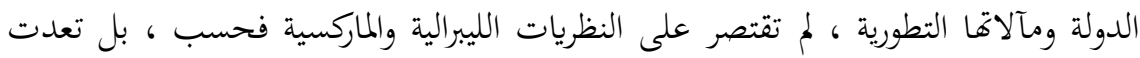

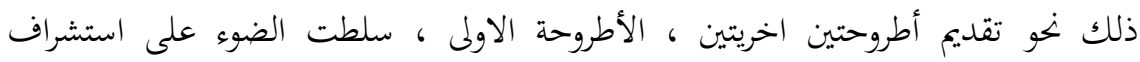

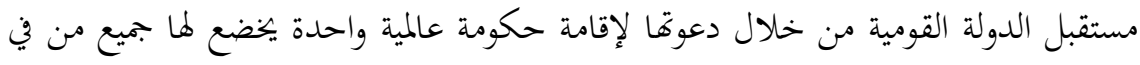

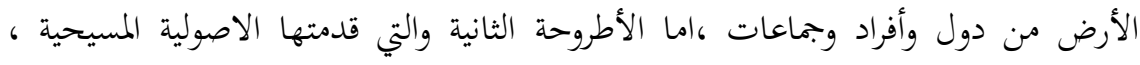
فسلطت الضوء على مستقبل الدولة الوضعية ومصيرها من خلال ماطرحته من افكار

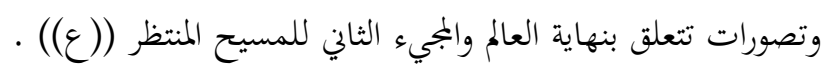

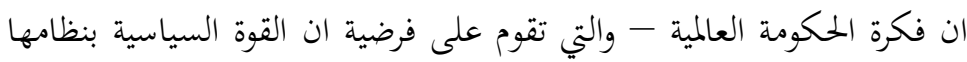

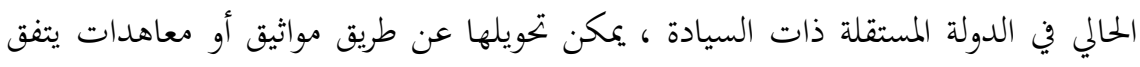

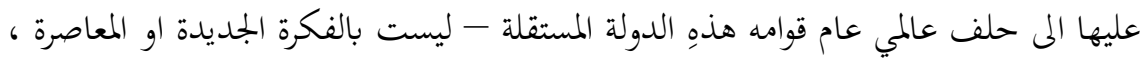

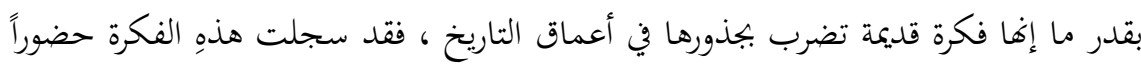

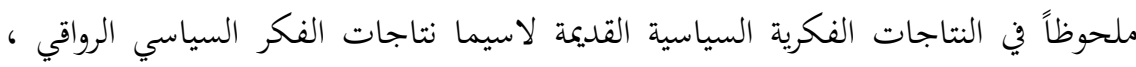

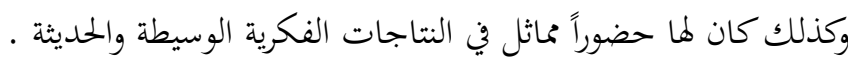

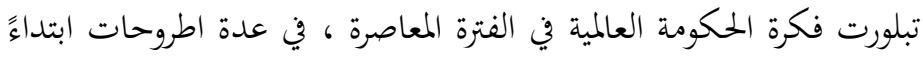

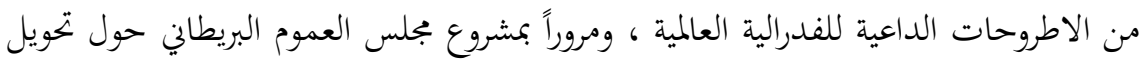

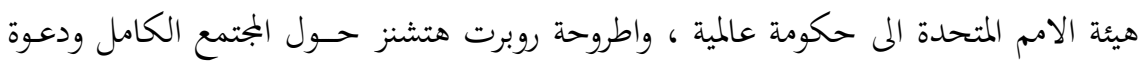

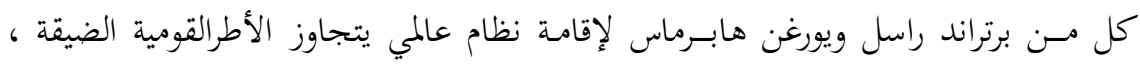

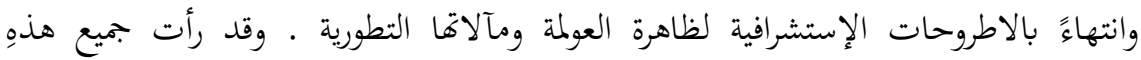
الأطروحات انه لا بجال لتجاوز واستيعاب تناقضات الدول القومية الا بقيام حكومة عالمية تأخذ على عاتقها تحقيق السلم والأمن الدوليين ، وتطبيق المبادئ التي تنشدها الإنسانية

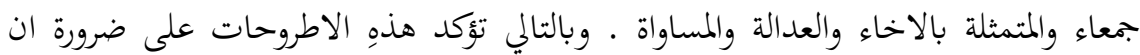

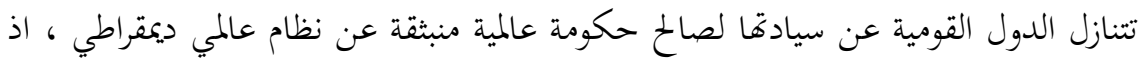

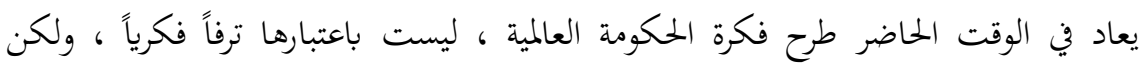

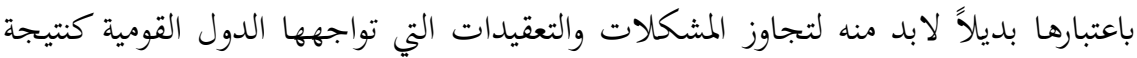

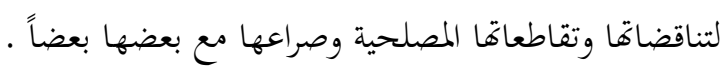


وهكذا ، فان الدعوات تنصب في الوقت الحاضر ، على ضرورة بتحاوز الأطر القومية الضيقة ، وضرورة اقامة وحدات سياسية كبيرة او عالمية دون اعطاء اهيمة لكيانات الدول ، وذلك بغية إيجاد أطر سياسية اكثر فاعلية من إطار الدول القومية .

\section{ملخص اطروحة دكتوراه}

ناقش طالب الدكتوراه حسن عودة ابو الهيل اطروحته الموسومة (اسس الطبقة

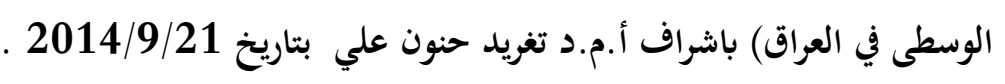
يعد مفهوم الطبقة الوسطى من المفاهيم السياسية والاجتماعية المهمة التي تناولها

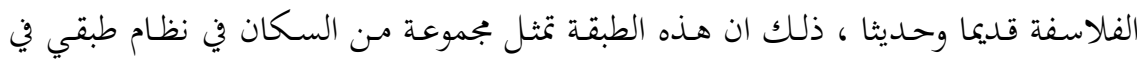

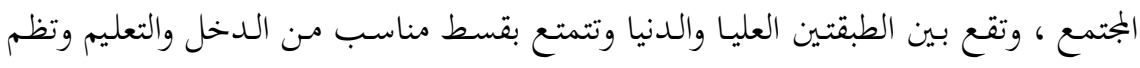

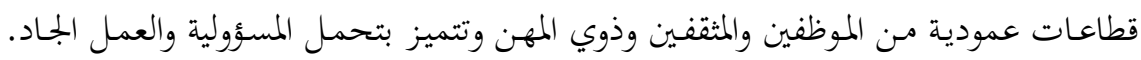

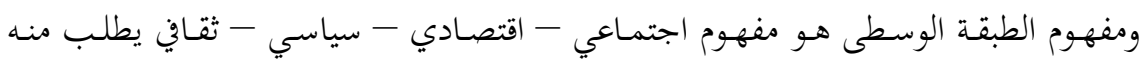

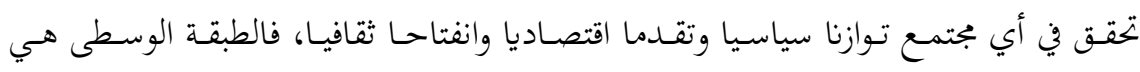

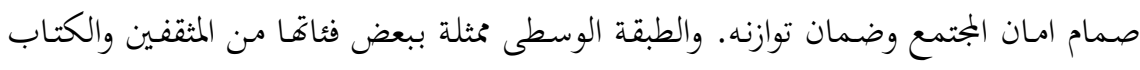

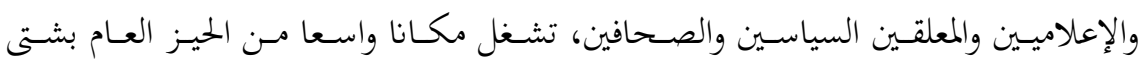

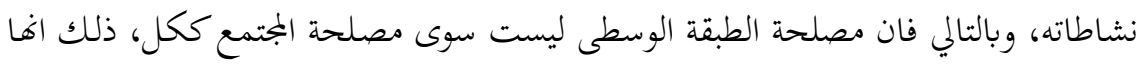

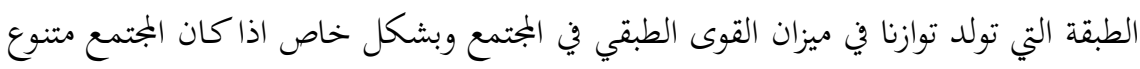
في تكوينه الاجتماعي طائفيا وقوميا واثنيا .

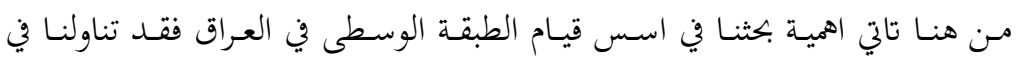

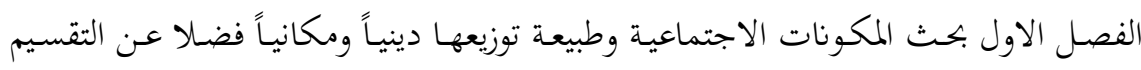

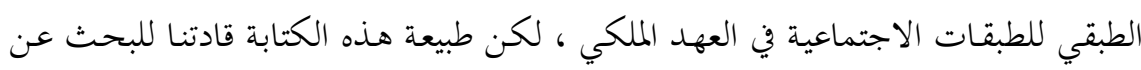

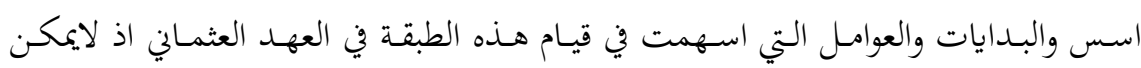

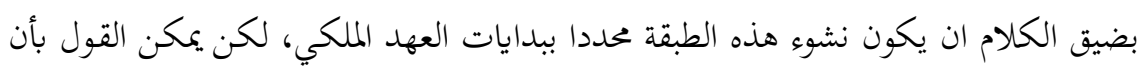

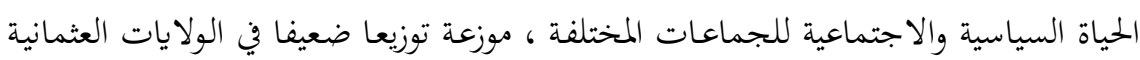
فكانت تلك المدن تقع ضمن محيط جيو - سياسي يختلف فيما بينها . 
لكن كانت هنـاك عوامـل سـاعدت في قيـام هـذه الطبقـات واجمـالا كـان للتغلغل

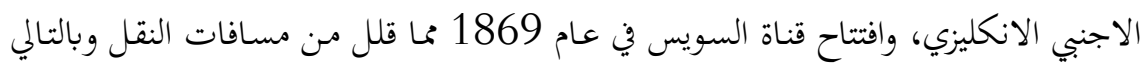

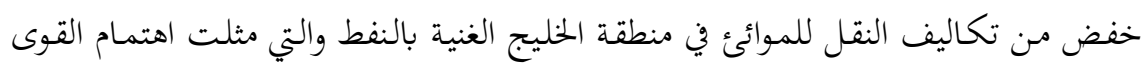

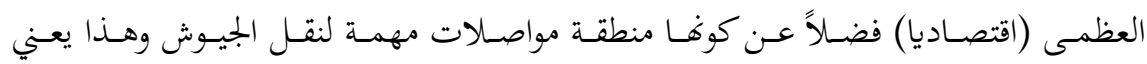

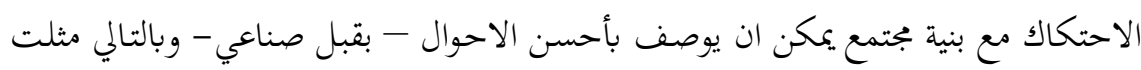

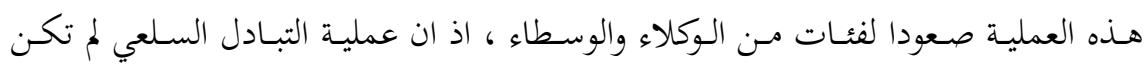

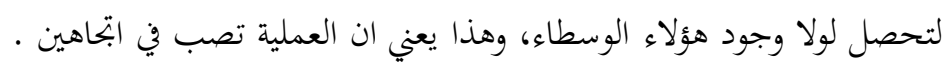
الاول - ان الناتج المحلي اصبح خاضعا لطبيعة السوق العالمية .

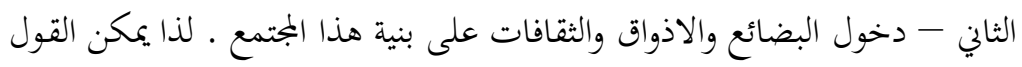

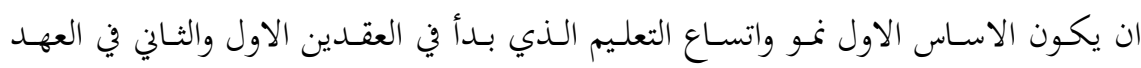

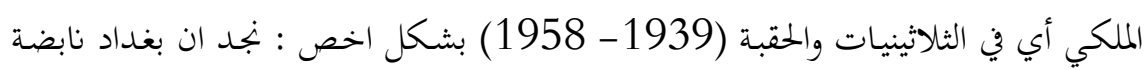

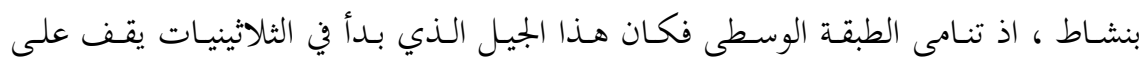
اقدامه في الخمسينات ويتقاطع مع الجيل القديم من (الاقطاع) وبشكل موات مع (الاغوات) و (البكوات) .

وبحلول عقدـ الخمسينات كـان هنـاك جيل جديـد يتقاطع مع الجيل القـديم وكـان

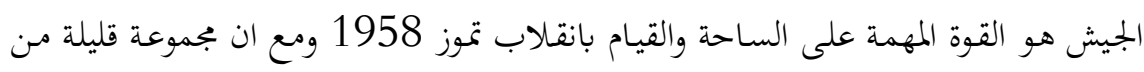

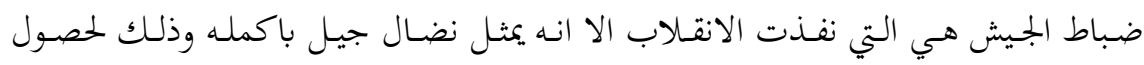

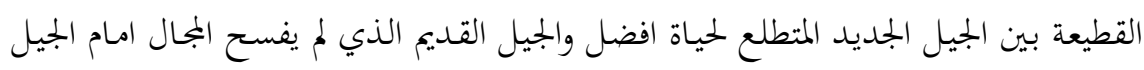

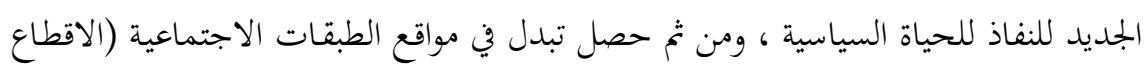

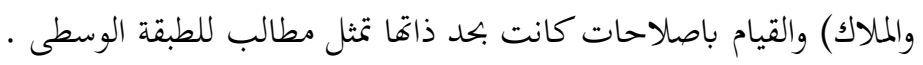

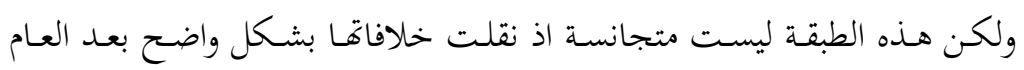

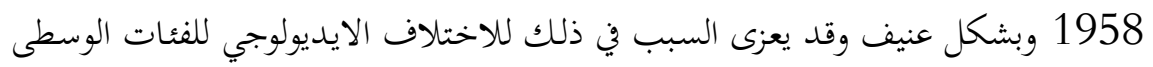

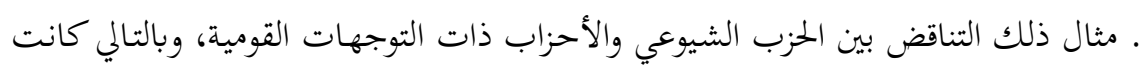

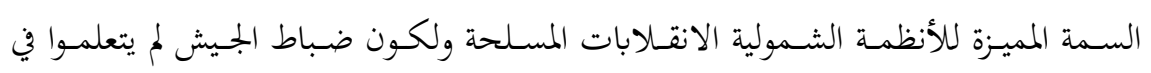


كليـاقم ومعاهـدهم ولا حتى في حيـاقم العملية مباديئ التداول السـلمي للسلطة فقد نقلوا

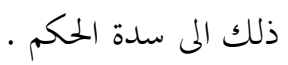

فكانت هذه الحقبة مـن (1958 - 2003) وهي حقبة مهمة وطويلة مـن الواقع

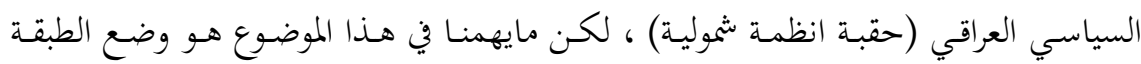
الوسطى .

اذ عملت هذه الانظمة على التوجيه العام للاقتصاد والسياسة وحتى الجانب الثقافي

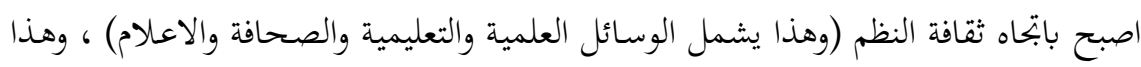

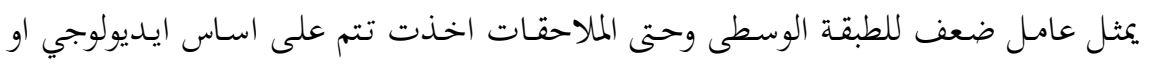

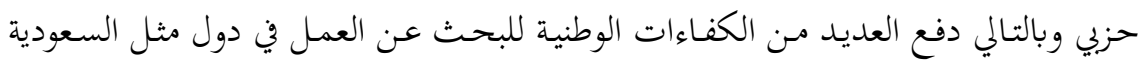

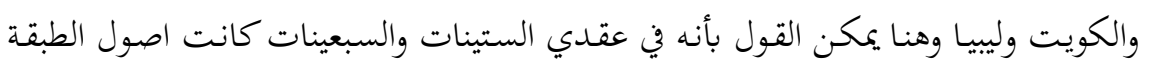

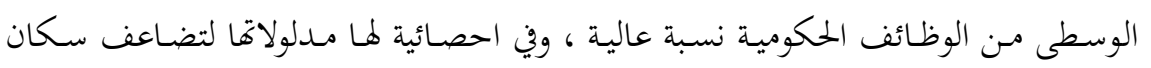

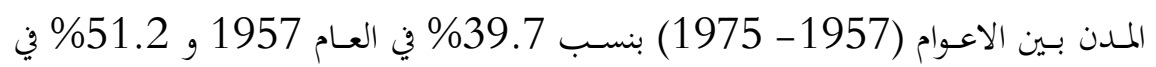
العام 1965 و63.00\% في العام 1975 منهم (19.6) مليون في العاصمة بغداد وحهدها

لكن هذه المكتسبات المتحققة في عقد السبعينات تلاشت في عقد الثمانينات اذ

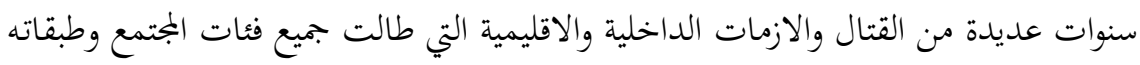

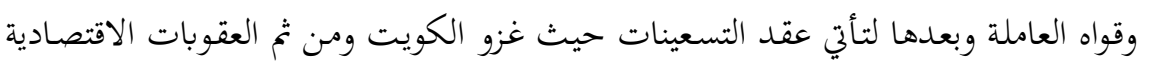

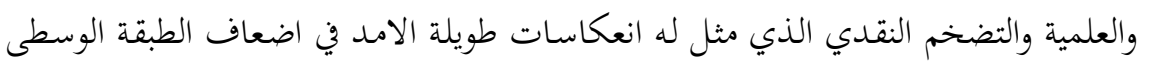
حيث اضعافها اقتصاديا واجتماعيا وسياسيا وثقافيا.

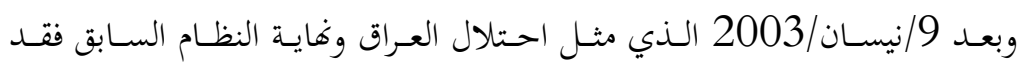

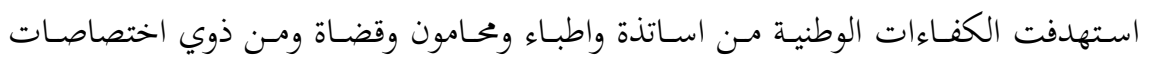

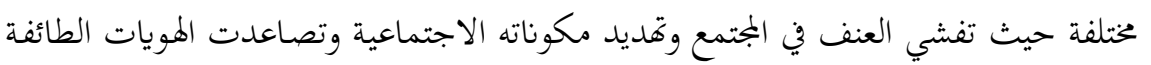
والفئوية على حساب الهوية الوطنية الجامعة . لذا والحالة هذه وفي محور دور الطبقة الوسطى من مرحلة التحول الديمقراطي نعتقد

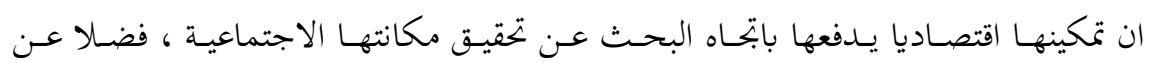


انتظامها في احزاب تمثل قيم (الوسطية) و (الاعتدال) وتؤمن بمبدأ(التداول السلمي للسلطة)

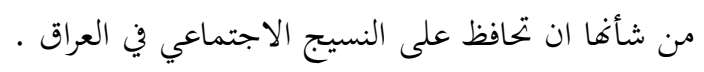

\section{ملخص اطروحة دكتوراه}

ناقش طالب الدكتوراه اسعد عبد الوهاب عبد الكريم اطروحته الموسومة (الفكر دئرو

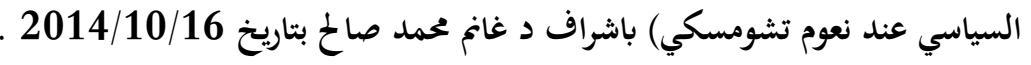

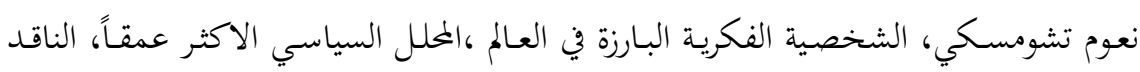

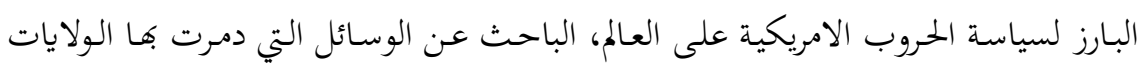

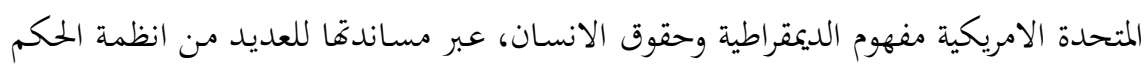
الفاسدة في العالم النامي.

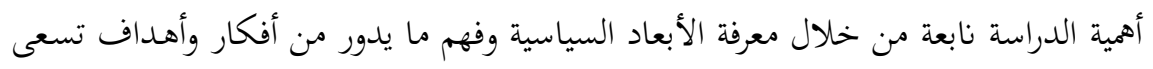

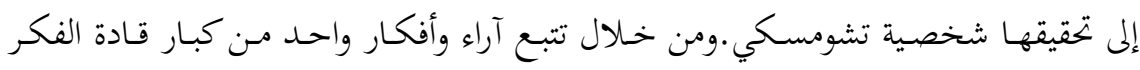
اليساري السياسي الأمريكي. فرضية الدراسة : يُعد نعوم تشومسكي مفكرا سياسياً معاصراً ، له نظريته واسلوبه الخناص

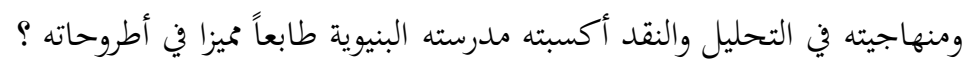

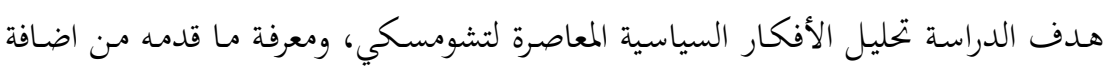

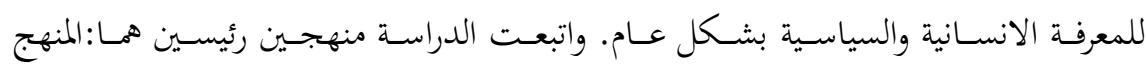
التحليلي والمنهج المقارن. تكونت شخصيته اثر عاملين رئيسيين هما : العائلة وبجموعة من الفلاسفة امثال ديكارت

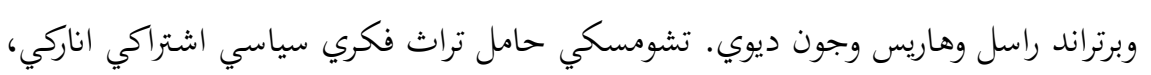
يعد احد منظري اليسار الامريكي وتيك دوري 
قسمت الدراسة الى خمسة فصول، الفصل الاول: تشومسكي: حياته، نتاجاته العلمية، المنهج

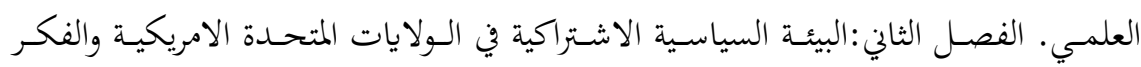

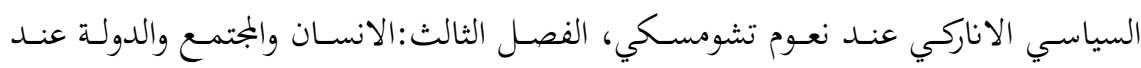

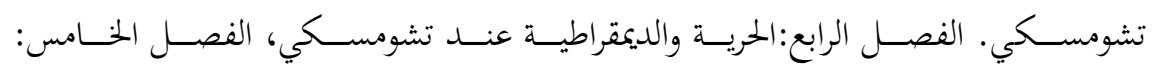
موقفتشومسكي من الارهاب والقضية الفلسطينية، وقد اثبتت الدراسة، ان نعوم تشومسكي مفكر سياسي معاصر، لـ له نظريته واسلوبه الخاص

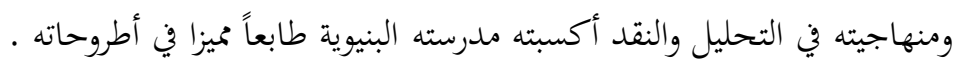

\section{ثالثـا: النشـاطات العلمبـة لفر ع النظم السياسـية لسـنة 2014- 2015}

\section{المناقشات}

في اطار النشاطات العلمية لفرع النظم السياسية جرت مناقشة عدد من أطاريح الدكتوراه

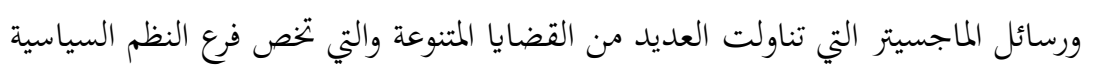

\begin{tabular}{|c|c|c|c|c|}
\hline & & & \multicolumn{2}{|c|}{ أطاريح الدكتوراه: } \\
\hline تاريخ المناقشة & عنوان الاطروحة & الاستاذ المشرف & اسم الطالب & ت \\
\hline $2014 / 8 / 5$ & الفيدرالية في العراق: & ا.م.د خميس حزام والي & عبد العظيم جبر حافظ & 1 \\
\hline $2014 / 10 / 2$ & جدلية الشراكة والمعارضة في النظام & أ.د بلقيس محمد جواد & عدي فالح حسن & 2 \\
\hline $\begin{array}{c}/ 10 / 14 \\
2014\end{array}$ & 2003: العملية السياسية في العراق بعد & ا. & احمد يميى هادي & 3 \\
\hline $\begin{array}{l}/ 10 / 12 \\
2014\end{array}$ & الضمانات الدستورية للحريات العامة & ا.م.د علي دريول محمد & زياد سمير زكي & 4 \\
\hline
\end{tabular}

رسائل الماجستير: 


\begin{tabular}{|c|c|c|c|c|}
\hline $2014 / 6 / 26$ & 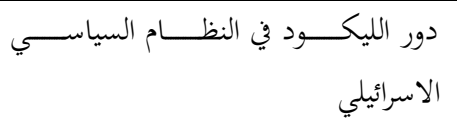 & ا.م.د علي درول محمد & حيدرمحمد منعم & 1 \\
\hline $2014 / 10 / 1$ & السلم الاهلي في العراق & م.د عمر جمعة عمران & منتصر حسين & 2 \\
\hline $2014 / 10 / 12$ & 2003 صـاحيات رئيس الوزراء في العـراق بعـد & الله & عبير محمد عبد & 3 \\
\hline $2014 / 10 / 22$ & 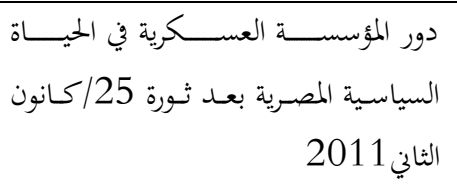 & ا..م.د ياسين محمد حمد & 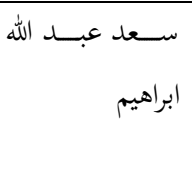 & 4 \\
\hline $2014 / 10 / 22$ & التجربة الاسبانية في التحول الديمقراطي & ا.م.د سعيد رشيد عبد & ياسر جميل باقر & 5 \\
\hline
\end{tabular}

\section{ملخص رسالة ماجستير}

ناقشت طالبة الماجستير عبير محمد عبد رسالتها الموسومة (صلاحيات رئيس الوزراء في العراق بعد 2003 :دراسة مقارنة) باشراف ا.د عبد الجباراحمد عبد الله بتاريخ 2014/10/12. تختلف الدول بتبنيها لنظام الحكم فيها من دولة الى أخرى ، فمنها من تأخذ بالنظام الرئاسي ومنها بالنظام البرلمان والأخرى بنظام الجمعية الوطنية ، كل حسب العوامل التأريخية

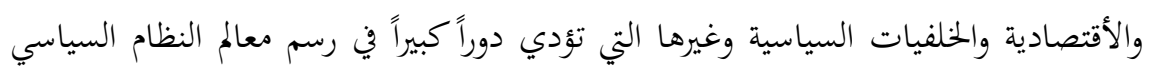
المناسب الذي تتبناه الدولة من أجل تنظيم السلطة فيها. وإذا كان هناك أكثر من نظام سياسي لأدارة الدول فأن العراق يعد أحد الدول التي أخذت بالنظام البرلماني منذ العهد

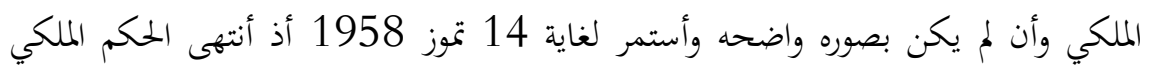

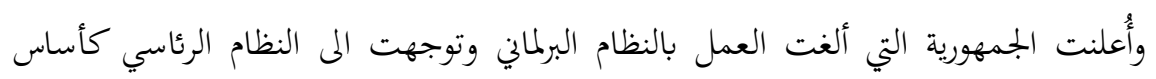
للحكم لغاية عام 2003. وبعد سقوط النظام السابق في 2003/4/9 مرت عملية بناء النظام السياسي العراقي بعدة مراحل بدأت بأدارة سلطة الائتلاف المؤقته مروراً بمجلس الحكم وأقرار قانون أدارة الدولة العراقية للمرحلة الأنتقالية تخم الحكومة المؤقته والحكومة الأنتقالية وأقرار

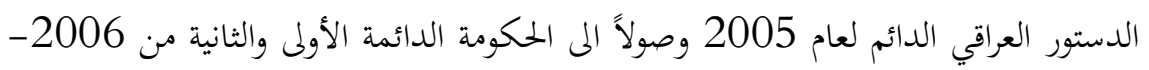
2014 وبأنتظار الثالثه ، ورافقت عملية بناء هذا النظام ظروف غير طبيعية أثرت بشكل كبير على طبيعة هذا النظام وعلى آليات عمله مما أدى بالنتيجة الى خلق خلل في توزيع 
الصلاحيات بين السلطات الثلاث ومنها صلاحيات رئيس الوزراء هذا الى جانب وجود مشكله في هيكلية النظام السياسي العراقي الجديد . مات ولهات لقد جاءت هذه الدراسة للبحث في طبيعة النظام السياسي العراقي وآليات عمله

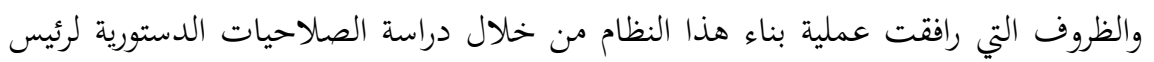

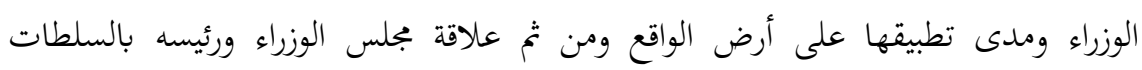

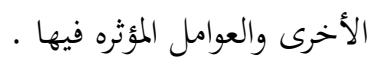

\section{ملخص رسالة ماجسيتر}

ناقش طالب الماجستير منتصر حسين جواد رسالته الموسومة (السلم الاهلي في العراق)

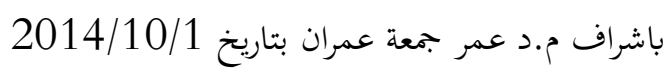

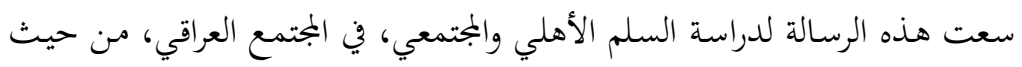

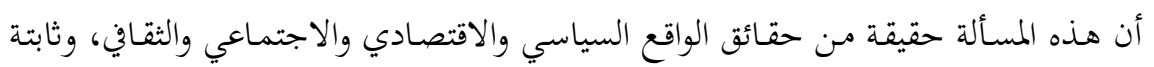

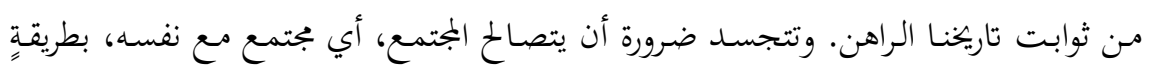

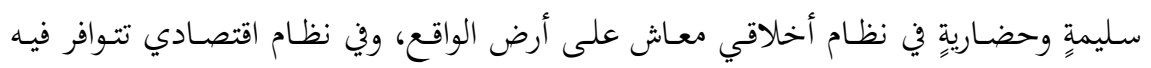
العدالة والمساواة وتكافؤ الفرص، وهكذا في نظام ثقافي واجتماعي وسياسي؛ لذلك فئل فإن السلم

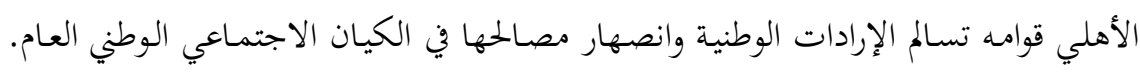

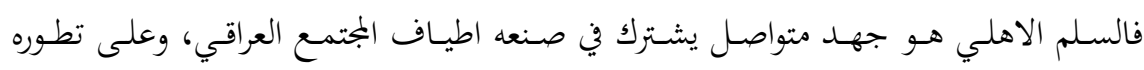

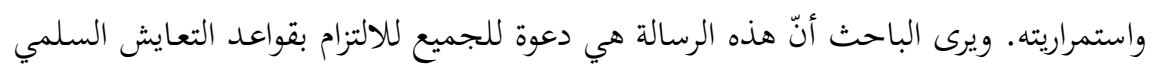

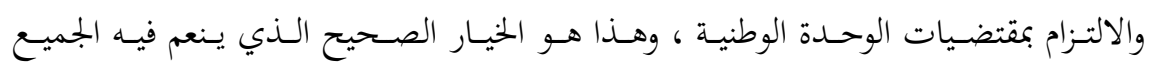

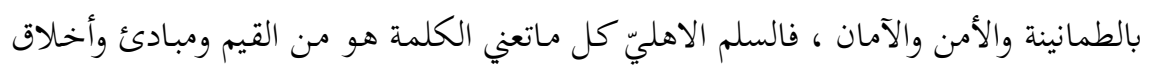
ونظم واستراتيجيات على الأصعدة كافة.

وقد بحثت الرسالة موضوعها في مقدمةٍ وثلاثة فصول وخاتمة ، تحدث الاصعة الفصل الأول

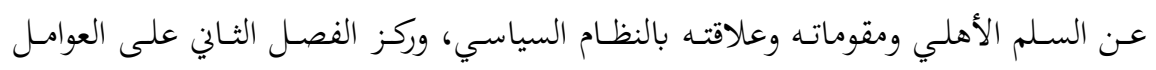

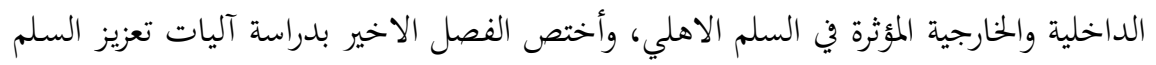
الاهلي السياسية والدستورية والاقتصادية والاجتماعية. ملخص رسالة ماسجيتز 
ناقش طالب الماجستير سعد عبد الله ابراهيم رسالته الموسومة (دور المؤسسة العسكرية في

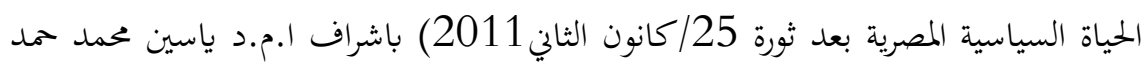

$$
\text { 2014/10/22 بتاريخ }
$$

تتمتع المؤسسة العسكرية المصرية بموقع مؤثر داخل الدولة, وتعد هذه المؤسسة بمثابة

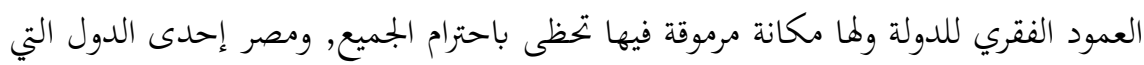

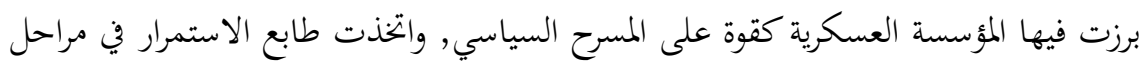

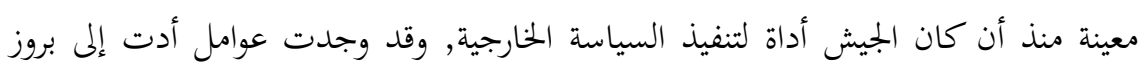
ظاهرة تدخل المؤسسة العسكرية في الحياة السياسية المصرية ومن هذه العوامل العامل التاريخي

$$
\text { والعامل الاجتماعي والعامل السياسي. }
$$

لقد غابت المؤسسة العسكرية عن الحياة السياسية في مصر مدة جاوسيا لاوزت الستين

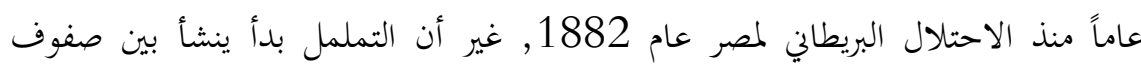

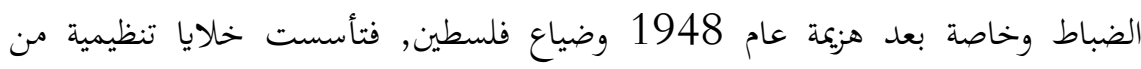

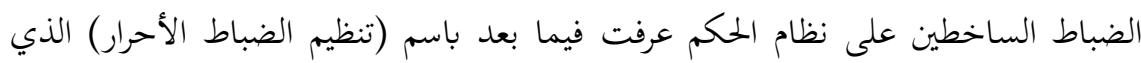

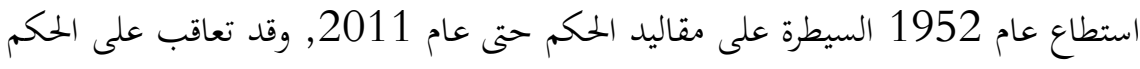
أربعة رؤساء جميعهم كانوا من صلب المؤسسة العسكرية (محمد نجيب وجمال عبد الناصر وأنور

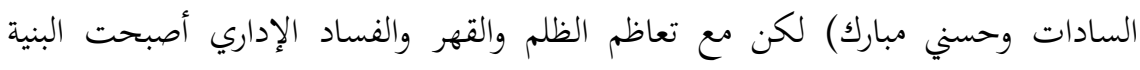

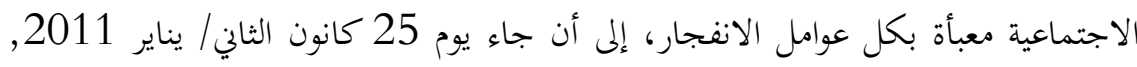

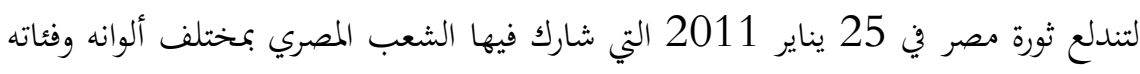
وطوائفه ولم تكن تلك الثورة وليدة لحظة بل كانت نتيجة تراكمات وإخفاقات عانى منها

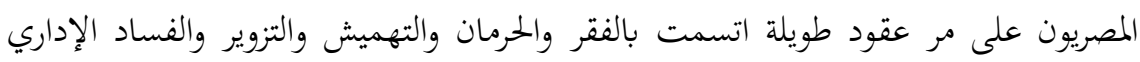

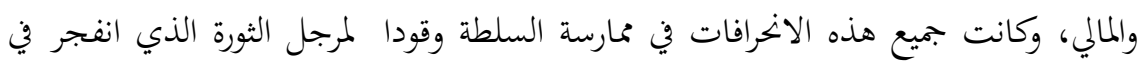

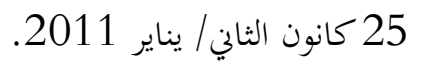

تعاملت المؤسسة العسكرية المصرية مع الثورة بدرجة عالية من المهنية والضبط فالحالة في مصر تختلف عن الحالة السورية أو الليبية، فالجيش المصري ليس مبنيا على طائفة أو

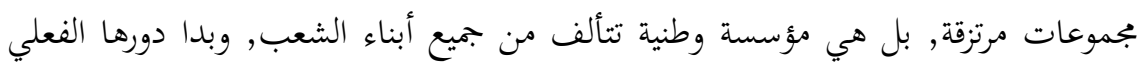


يتضح علانية في اليوم السابع عشر من عمر الثورة الذي استمر (18) يوما، إذ تحدث بيان

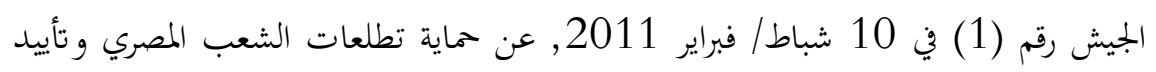

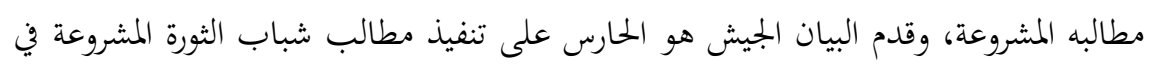
إطار الشرعية الثورية.

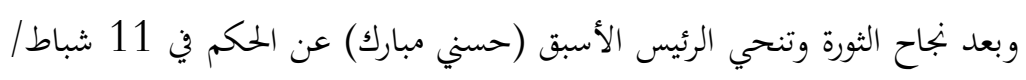

فبراير 2011, أصبح المجلس الأعلى للقوات المسلحة وفق الإعلان الدستوري الصادر في 13

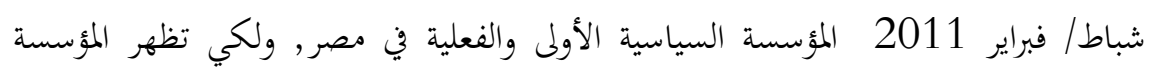

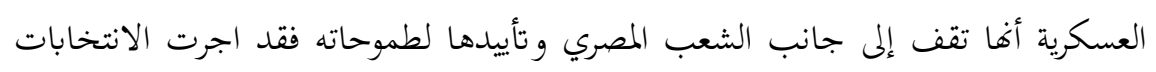
التشريعية والرئاسية وقد أفرزت هذه الانتخابات سيطرة التيار الإسلامي متمثلا في (الإخوان

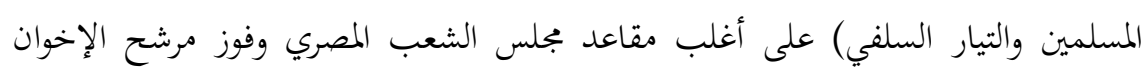

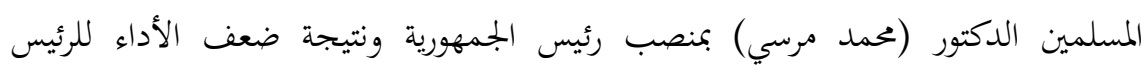

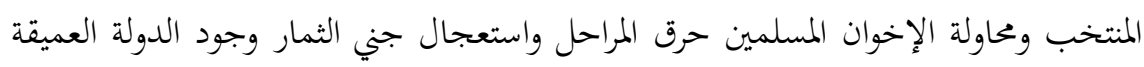

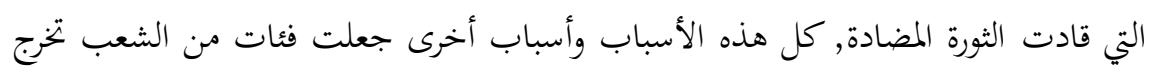

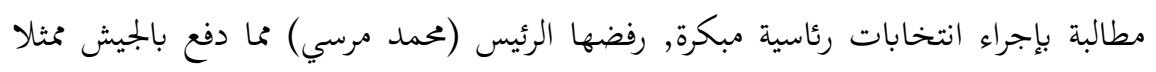

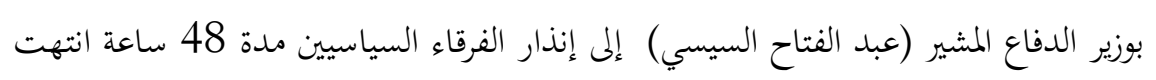

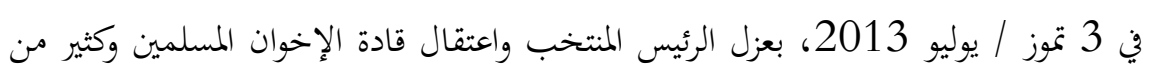

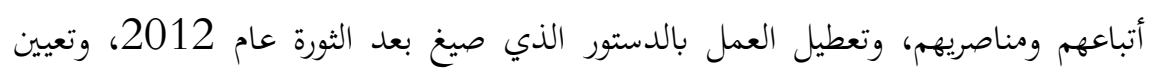

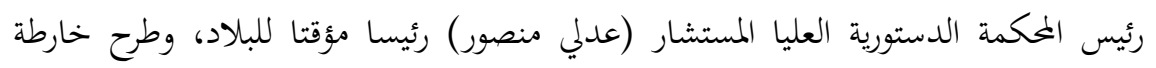

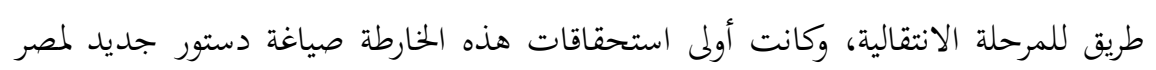

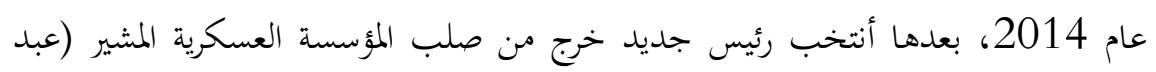

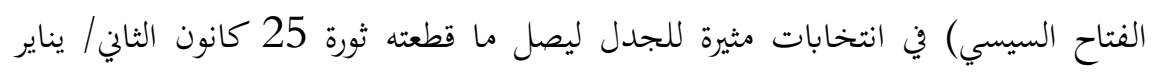

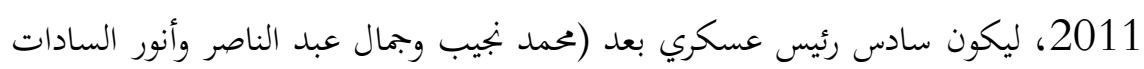
وحسني مبارك ومحمد طنطاوي رئيس المجلس الأعلى للقوات المسلحة). 
ناقش طالب الدكتوراه عدي فالح حسن اطروحته الموسومة (جدلية الشراكة والمعارضة في

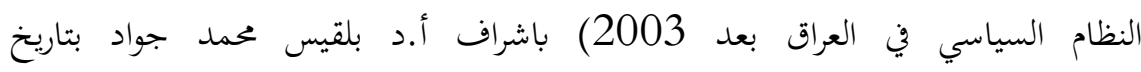
2014/10/2

توصف الشراكة السياسية بأغا احدى اهم مؤشرات النظم السياسية التي تمر بمراحل التحول

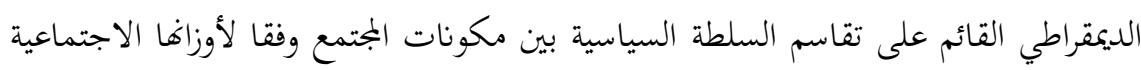

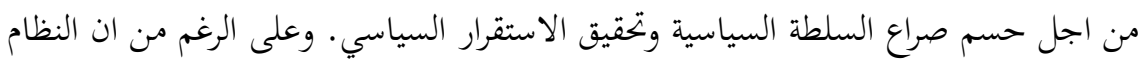

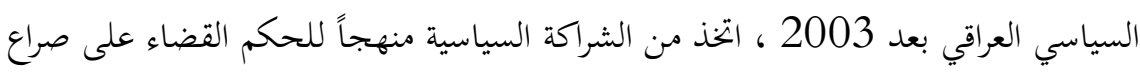

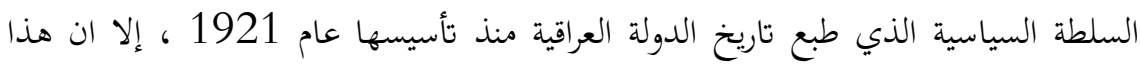

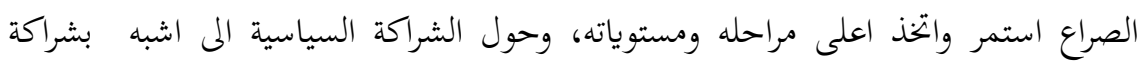

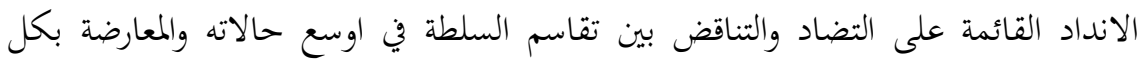
اشكاها وأدواتما.

وانطلاقا من اهمية الموضوع وكونه يتعلق بحاضر ومستقبل النظام السياسي العراقي،

حاول البحث دراسة واقع العراق السياسي بعد 2003 القائم على تبني احدى اهم النظريات

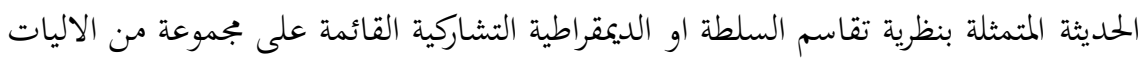

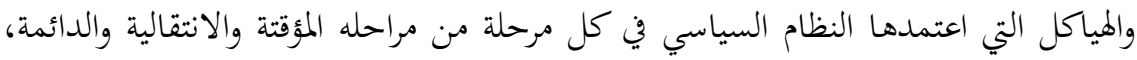

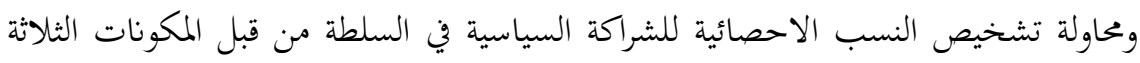

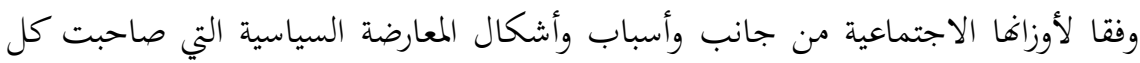

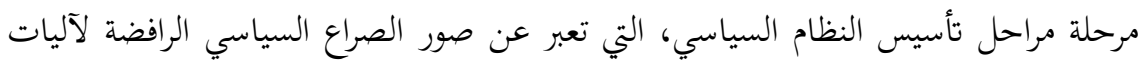

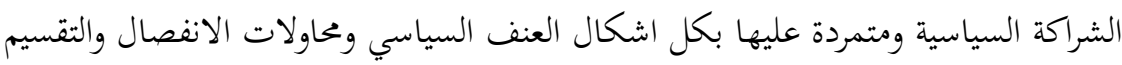

تناول البحث الشراكة السياسية بكل الياتا ومستوياتما في اطار النظام السياسي

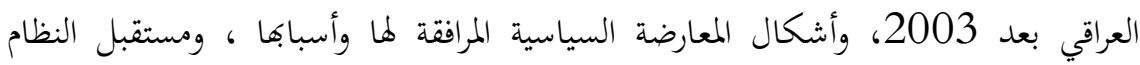
السياسي في ظل التناوب والتضاد بين الشراكة والمعارضة السياسية في اربعة فصول ، الاول تناول الاطار النظري للبحث وانقسم الى ثلاثة مباحث ، تناول المبحث الاول مفهوم النظام

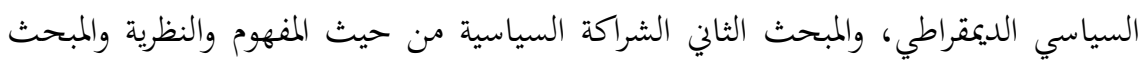


الثالث المعارضة السياسية بكل اشكالها . وتناول الفصل الثاني ظروف النشأة والتكوين

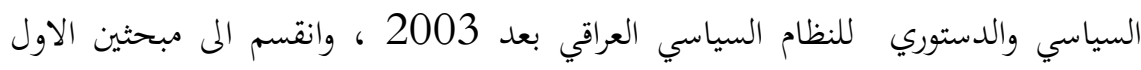

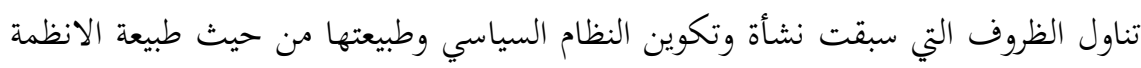

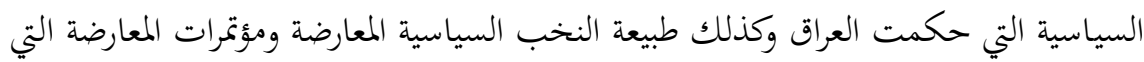
عقدةا واهم المواثيق والاتفاقيات التي خرجت بها بشان شكل النظام السياسي المقبل ،

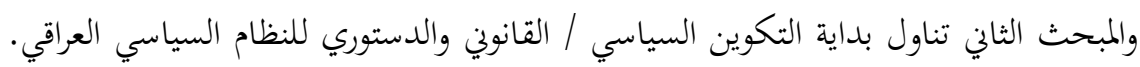

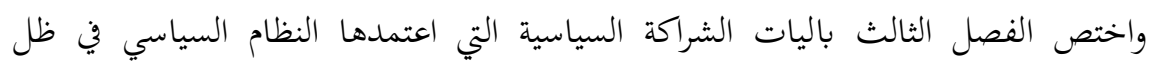

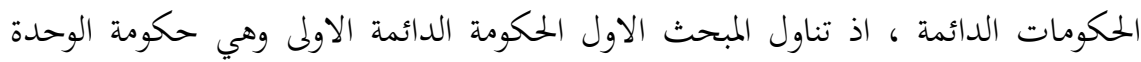

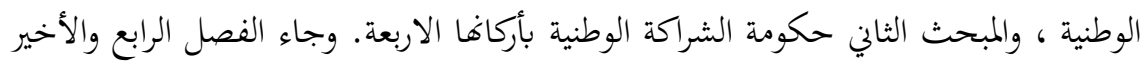

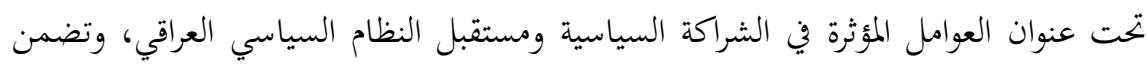

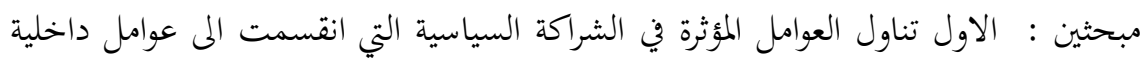

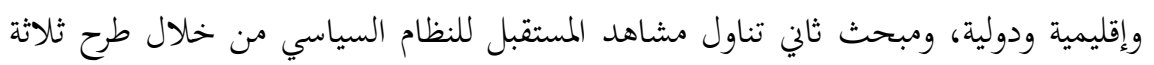

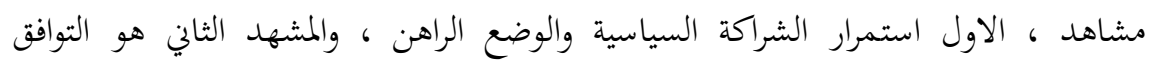

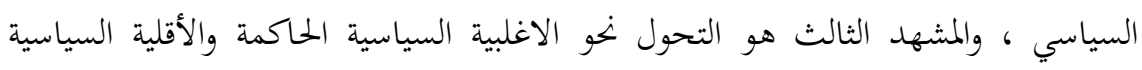

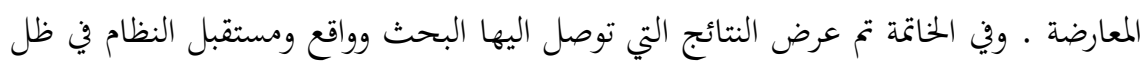
المشاهد الثلاثة الراهنة والمستقبلية. 
